\title{
Messianism as a Philosophical Problem: The Liber de Adventv Messiae by Ramon Llull
}

\author{
Celia López Alcalde \\ Instituto de Filosofia, Universidade do Porto \\ uranias.celia@gmail.com
}

\begin{abstract}
The Liber de aduentu Messiae is one of Ramon Llull's major contributions to JewishChristian polemics. However, oddly enough, it has been neglected by scholars. The present study consists of two parts: the first contains an analysis and description of certain contextual and internal features of the work in question; and the second a critical edition of the text, which until now has remained unedited in its totality.
\end{abstract}

\section{Keywords}

Messianism - Religious polemics - Liber de aduentu Messiae - Ramon Llull

\section{1 \\ Introduction to the Liber de aduentu Messiae}

The Liber de aduentu Messiae (LAM) belongs to that group of works by Ramon Llull, which, since they remain unedited, have received little attention within

* Research member at the Instituto de Filosofia of the University of Porto, Via Panorâmica s/n, 4150-564 Porto, holding a postdoctoral fellowship provided by the Portuguese Fundação para a Ciência e a Tecnologia, ref. SFRH / BPD / 95373 / 2013. Research for this paper was conducted in close collaboration with the ERC-project "The Latin Talmud" (FP7/2007-2013, $\left.n^{\circ} 613694\right)$. I gratefully acknowledge the invaluable collaboration of Alexander Fidora and Robert D. Hughes, and the relevant suggestions made thereby. I would like also to thank to the research group Islamolatina (Universitat Autònoma de Barcelona) its support. Finally, I am very grateful as well to David Nirenberg and Mark D. Johnston for his exceptional kindness and hospitality during my research stay in Chicago. 
the fields of either Lullian scholarship or medieval polemics. ${ }^{1}$ We now provide, therefore, the first complete and critical edition of this text.

Unfortunately, the work itself does not give any explicit indication of its date of composition, as is also the case with many other medieval texts. Despite this inconvenience, however, a fairly reliable set of dates can be establishednamely, between 1274 and 1284-thanks to several pieces of evidence which indicate that it was most probably written during Llull's stay in Montpellier. ${ }^{2}$ Such evidence principally consists of the following: first, the reference to the Liber contra Antichristum; ${ }^{3}$ second, LAM's textual typology, i.e. its status as a dialogue concerning religious topics which bears some resemblance to the Llibre del gentil e dels tres savis; ${ }^{4}$ third, the postulation of sixteen "Dignities" (i.e. God's attributes, which serve as the onto-theo-logical principles of Llull's

1 "Das Werk selbst wurde bisher in del Lullforschung — soweit ich sehe-noch nicht genauer behandelt, da es als ganzes bis jetzt nie ediert wurde und auch nur in einer Handschrift aus dem 14. Jahrhundert, dem Ms. 500 der Bibliothèque de la Ville von Reims $\left(\right.$ fol. $\left.133^{\text {ra }}-149^{\text {ra }}\right)$ vollständig überliefert ist.” Walter Andreas Euler, “«De adventu Messiae»: Ramón Lulls Beitrag zur christlich-jüdischen Messiaskontroverse," in Aristotelica et Lulliana magistro doctissimo Charles H. Lohr septuagesimum annum feliciter agenti dedicata, ed. Fernando Domínguez, Ruedi Imbach, Theodor Pindl, and Peter Walter (Steenbrughe / The Hague: Abbatia Sancti Petri-Martinus Nijhoff International, 1995), 429-441, here 430.

2 Montpellier seems not to have been his permanent residence, but rather the place from which he set out upon his journeys, for instance to Majorca, cf, Fernando Domínguez, Jordi Gayà, "Life," in Raimundus Lullus, An Introduction to his Life, Works and Thought, "Raimundi Lulli Opera Latina. Supplementum Lullianum" II, ed. Alexander Fidora and Josep Enric Rubio (Turnhout: Brepols, 2008), 3-124, here 49-51, 53 .

3 " [...] cui christianus placide respondens dixit se satis sufficienter cum eo disputasse, et excusans se, eo quod tractaturus erat de quodam libro quem compilauit contra Antichristum et aduentum eius." $L A M$, Epilogue. This fragment seems to indicate that both books were written at the same time, and, in fact, the books share some of their argumentations (cf. nn. 184 and 209 of our edition).

In relation to the Liber contra Antichristum, Jordi Pardo relates the work to Llull's antiMuslim polemics, where Antichrist is identified with Mohammed. In this case, Llull would write nearly at the same time against both Jews and Muslims. Nevertheless, Josep Perarnau had already considered that the Liber contra Antichristum is a work composed to critize the Church and Papacy, cf. Jordi Pardo Pastor, "Mahoma y el Anticristo en la obra de Ramon Llull," Anales del Seminario de Historia de la Filosofía 22 (2005): 159-175; Josep Perarnau, "Pròleg," in Ramon Llull, Llibre contra Anticrist, "Arxiu de Textos Catalans Antics 9" (1990), 29. In our opinion, the text is not explicit enough to identify the Antichrist with Mohammed or Islam.

4 "Die Szenerie des Prologes ist aus anderen Werken Lulls, etwa dem Liber de gentili et tribus sapientibus." Euler, “«De adventu Messiae»: Ramón Lulls Beitrag ...," 431. 
Art) instead of the nine which appear in Llull's later period; 5 and last, its methods of argumentation, which are typical of the early phase of Llull's literary production. ${ }^{6}$ Within this broad temporal framework, as Joan Santanach has pointed out, the fact that, when discussing the Antichrist, the Doctrina pueril fails to mention the Liber contra Antichristum as the point of reference for a more in-depth treatment of this question, might suggest that in 1276-namely, the date at which the former was completed - the latter had not yet been written. One could draw the same conclusion, in fact, as regards $L A M .^{7}$

As previously mentioned, the content of $L A M$ belongs to the literary tradition of Jewish-Christian polemics. The text unfolds according to a dialogical model, a dialogue, that is, conducted between a Jew and a Christian sage, who discuss the arrival of the Messiah. The polite attitude of each speaker vis-à-vis the other-an attitude found likewise in the Llibre del gentil—is particularly worthy of note. ${ }^{8}$

\section{Contents of the Work}

In terms of its structure, the book is divided into three principal sections: i) a prologue; ii) the discussion proper-containing two distinct parts: first, the speech delivered by the Jew and, second, that delivered by the Christian; and iii) an epilogue, with which the work closes.

5 From the time of the Ars inuentiua ueritatis (ca. 1290) onwards, Ramon Llull reduced the number of Dignities to nine, see Euler, “«De adventu Messiae»: Ramón Lulls ...," 433; Robert Pring-Mill, Estudis sobre Ramon Llull (Barcelona: Curial, Abadia de Montserrat, 1991), 118. The work would thus have been written during the quaternary phase, according to the chronology established by Anthony Bonner, namely the revised chronology in Anthony Bonner, "Modificacions al catàleg d'obres de Ramon Llull," Estudios Lulianos 26 (1986): 81-92, here 8185; About this quaternary phase and its evolution in detail, see, Anthony Bonner, The Art and Logic of Ramon Llull: A Users Guide (Leiden: Brill, 2007), 26-120. From 1294 onwards, Ramon Llull customarily indicated the date and place of composition of his works. See Domínguez and Gayà, "Life," in Raimundus Lullus, An Introduction ..., 11.

6 See Euler, “«De adventu Messiae»: Ramón Lulls Beitrag ...," 437.

7 See Joan Santanach i Suñol, "Notes per a la cronologia del cicle de l'«Ars compendiosa inueniendi ueritatem»," Studia Lulliana 40 (2000): 23-46, here 31-34, 42.

8 Indeed, the pacifism exhibited in the work has lead Josep Perarnau to consider situating the work before 1274, the date of the Second Council of Lyon, in which legitimation was given to the use of force for the purpose of facilitating conversions; cf. Josep Perarnau i Espelt, "El Llibre contra Anticrist de Ramon Llull. Edició i estudi del text," Arxiu de Textos Catalans Antics 9 (1990): 7-182, here 48-49. 


\section{i) Prologue}

The prologues are frequently the ideal place to introduce not only the content but also to underline certain specific aspects of the work itself. ${ }^{9}$ In this particular case, the content concerns the arrival of the Messiah. Ramon Llull thus addresses the most hotly debated question within Judaeo-Christian polemics, insofar as the belief in the arrival of the Messiah in times past, as contended by Christians, or in the future, as proclaimed by the Jews, constituted the specific difference between both religions. On this subject of the arrival of the Messiah, Llull's polemics against Judaism are distinguished from the polemics with Islam, wherein other arguments are presented. ${ }^{10}$ Indeed, it constituted a difference which militated against the interests of members of both religions, as one of the two disputants in fact complains. ${ }^{11}$

The prologue of $L A M$ also presents, however, the guidelines to be followed as regards the interlocutors' lines of reasoning, these guidelines being established by consensus. Such consensus relates chiefly to the following aspects:

9 For the prologue to $L A M$, cf. the analysis by María del Carmen Fonollet, to whom we should like to extend our thanks for her collaboration and generosity during the elaboration of this study. See María del Carmen Fonollet Paños, Estudio, comentario y traducción del prólogo del De aduentu Messiae de Ramón Llull, (M.A. Thesis, Autonomous University of Barcelona, 2011), which was written under the direction of Cándida Ferrero Hernández. See also Celia López Alcalde, "El Liber de adventu Messiae de Ramon Llull y la literatura "adversus Iudaeos" del siglo XIII", in, Latinidad Medieval Hispánica, ed. Francisco Mesa Sanz (Firenze: SISMEL-Edizioni del Galluzzo, 2017), 223-232. As Óscar de la Cruz pointed out: "Ahora bien, los argumentos de la discrepancia doctrinal son, además de la divina encarnación y de la Trinidad, otros: los cristianos se alejan de los musulmanes cuando dicen que Dios es también el responsable de los pecados de los hombres. Esta es, en definitiva, la discrepancia sobre el libre albedrío. Además, los musulmanes alegan que el mundo es finito en el tiempo, sobre lo cual hay acuerdo, excepto en que incluyen la perdurabilidad de los ángeles. También hay puntos en común sobre la resurrección, sin embargo discrepan en cuanto al relato de lo que ocurrirá en el día del juicio final." Óscar de la Cruz Palma, "Raymundus Lullus contra Sarracenos: el islam en la obra (latina) de Ramón Lull," Cahiers d'études hispaniques médiévales 28 (2005): 262. $L A M$, Prologue: "Heu me, quantus error per uniuersum orbem uertitur, licet non habeamus nisi unum solum Deum, unum creatorem, unum super omnia dominantem. Et nos quidem omnes homines alii contra alios diuisi sumus, credendo in illum, et in illo et per illum inter nos inimici et contrarii facti sumus; qua siquidem inimicitia et contrarietate sunt guerrae, proelia, mortes, seruitutes et multa inde malorum genera sortiuntur, quae nequaquam essent si nos uniuersi in una fide, una credulitate tantum unanimiter sisteremus." 
- Establishing a fair (or just) sequence for the speeches. According to this criterion of justice, the Jew will rightfully be responsible for commencing the dialogue. Such priority is attributable to historical factors, insofar as the Jew acts as representative of the first people to have received the authentic Law from God. ${ }^{12}$

- The types of arguments to be employed. The interlocutors agree to consider as valid only those arguments based upon reason and not those which rely upon auctoritates. ${ }^{13}$ The choice of this species of argumentation, and the absence of any reference to authorities, provide the pattern followed by almost all of Llull's speculative works. In the context of inter-religious polemics, the use of Christian authorities to defend Christianity is conceived by him as a strategic error, on account of such authorities' incapacity to constitute effective forms of persuasion. This limitation is even applicable to the citation of Old Testament texts, since the mere act of interpreting them calls forth endless dispute, as is pointed out in the text. ${ }^{14}$ For these reasons, Ramon Llull will dismiss the use of arguments from authority in the conversion of "infidels," certain rare cases excepted. Precisely one such exception is his other work directed ad Iudaeos, namely, the Liber praedicationis

12 LAM, Prologue: "[...] cui [iudaeo] christianus respondit dicens se nolle primo incipere, nam insinuabat rationis ordo quod iudaeus primo inciperet ratiocinari, eo quod lex uetus iudaica multo prius traxit exordium quam noua lex christiana." The same idea appears in the Doctrina pueril: "La ley veyla fo per so que fos comensamens e fonaments de la nova, e la ley nova fo per so que fos lo fruyt e.l compliment de la veyla; e assó es, fil, de totes cozes segons ley natural, cor so qui es primer cové esser fondament e so qui es enaprés es lo fruyt e.l compliment." Ramon Llull, Doctrina pueril, "Nova Edició de les Obres de Ramon Llull” viI, ed. Joan Santanach i Suñol (Palma de Mallorca: Patronat Ramon Llull, 2005), 28-31.

$13 L A M$, Prologue: "Cum per auctoritates ueritatem aduentus Messiae cognoscere nequeamus, saltem temptare bonum est, si eius aduentum cognoscere poterimus per necessarias rationes, nam ratio necessaria est aptior magisque intellectui apprehensiua quam glossae seu expositio auctoritatum, et ideo bonum est ut disputemus per rationes necessarias et inquiremus Messiae aduentum diligenter, prout ordo dictauerit rationum." Cf. Anthony Bonner, "Lart lul.liana com a autoritat alternativa," Studia Lulliana 33 (1993): 15-32; Pere Villalba, "Reminiscencias ciceronianas en Ramon Llull," Convenit Selecta 7 (2001): 81-86; Horacio Santiago-Otero, La Biblia en la Península Ibérica durante la Edad Media (siglos $X I I-X V$ ): el texto y su interpretación (Coimbra: Arquivo da Universidade de Coimbra, 2001), 87-95.

$14 L A M$, Prologue: "Maxime disputatio et controuersia uertebantur inter hos duos sapientes in prophetarum expositione, nam eorum quilibet conuertebat suae intentioni per glossas textum legis ueteris et prophetarum." 
contra Iudaeos of $1305,{ }^{15}$ a work in which biblical authority and philosophical reasoning are combined. As we shall see further on, in combining these, Ramon Llull acts in accordance with the standard manner of conducting polemics. This considerable change of approach-from the disputatio form to the sermon-seems to reflect an evolution away from his earlier optimism regarding reason as a key tool for conversions towards a sense of disillusionment. At the same time, this evolution coincides with his desire to exhibit unconditional adherence to the Catholic Church during his later years. ${ }^{16}$

- The divine Dignities and virtues are used as premises in the argumentation. $L A M$ calls for discourse that is based exclusively upon rational arguments, arguments which should be founded upon loci communi. In Llull's view this procedure is of overriding importance in the dialogue with Abrahamic Religions, for the reason that on the basis of previously accepted conditiones alone can dialogue function properly. ${ }^{17}$ In dialogue with Judaism, besides the existence of a single God, these premises, shared by both religions, consist in: the divine Dignities, which correspond to the highest degree of perfection in God; the goodness of the seven virtues, which bring man closer to God; and the concordance between these virtues and the divine Dignities. ${ }^{18}$

15 Editions: Ramon Llull, Liber praedicationis contra Iudaeos, ed. José María Millás Vallicrosa (Madrid / Barcelona: CSIC, 1957); "Raimundi Lulli Opera Latina" XII, ed. Alois Madre (Turnhout: Brepols, 1984).

16 Ramon Llull thus states in the prologue to the Liber praedicationis contra Iudaeos: "Et si forte in isto libro errauerimus contra sanctam fidem catholicam, aut improprie locuti erimus, submittimus ipsum ad correctionem sanctae fidei catholice." (Ed. J. M. Millás Vallicrosa, 71).

17 According to Sebastián García Palou, the polemics with Islam, and the rational idiosincrasy of Muslim tradition in Majorca was the cause of the introduction of the rationes necessariae in Llull's writings. Cf. Sebastián García Palou, Ramon Llully el Islam (Palma de Mallorca: Impresos Lope, 1981), 141-171. Indeed, as remarked in García Palou's study, Llull's concern with Islam was stronger than with Judaism, a fact well reflected in his works and journeys to Muslim countries.

18 LAM, Prologue: "Prima enim conditio est de diuinis dignitatibus, quae sunt bonitas, magnitudo, aeternitas, potestas, sapientia, amor, perfectio, gloria, uirtus, ueritas, iustitia, largitas, misericordia, humilitas, dominium et patientia, atque caeterae in istis omnibus uersantur [...]. Secunda uero conditio est de diuinis dignitatibus et septem uirtutibus, quibus mediantibus tenditur ad gloriam et obstatur uitiis et peccatis, quae quidem uirtutes sunt hae, uidelicet fides, spes, caritas, iustitia, prudentia, fortitudo, temperantia [...]. Tertia autem conditio est de septem uirtutibus antedictis, uidelicet ut rationes quae in aduentu Messiae maiorem denotabunt concordantiam inter unum actum uirtutis et alterum, sint affirmabiles et amentur [...]." 
In the presuppositional context of monotheism, the divine Dignities and the virtues perform a central role within the dialogue. Scholars have already highlighted the relevance of the divine Dignities in Ramon Llull's thought, since these constitute one of its most fundamental features. In the context of polemics with Jews, however, they acquire an even more meaningful role, as has been pointed out by scholars who have studied Llull's relations with Jews and with Jewish thought. The relation of Llull's system, namely, the Art, with Kabbalistic thought has been emphasised in particular. ${ }^{19}$ The doctrines of this Jewish movement (with its numerical combinations and its mysticism), based as it was on faith in an infinite God, at once hidden (En sof) yet having dynamic emanations (sefirot), ${ }^{20}$ and who made and makes Creation possible, have been reckoned to be a very significant influence upon Llull. There can be no doubt that Ramon Llull establishes a link between this Jewish conception and his own Christian theological view, placing, as he does, the Dignities from the Latin tradition and the divine manifestations as conceived by the Kabbalah on the same level, in order to establish them, in addition to faith in a single God, as one of the fundamental points of doctrinal agreement between Christians and Jews. ${ }^{21}$

19 See among others, José María Millás Vallicrosa, "Algunas relaciones entre la doctrina luliana y la Cábala," Sefarad 18 (1958): 241-253; Moshe Idel, "Ramon Llull and Ecstatic Kabbalah," Journal of the Warburg and Courtauld Institutes $5^{1}$ (1988): 170-174; Moshe Idel, "Dignitates and Kavod: Two Theological Concepts in Catalan Mysticism," Studia Lulliana 36 (1996): 69-78; Eusebi Colomer, "Ramón Llull y el judaísmo en el marco histórico de la Edad Media hispana," Estudios Lulianos 10 (1966): 5-45; 12 (1968): 131-144; Eusebi Colomer, "La actitud compleja y ambivalente de Ramon Llull ante el judaísmo y el islamismo," in Constantes y fragmentos del pensamiento luliano. Actas del simposio sobre Ramon Llull en Trujillo, 17-20 septiembre 1994, ed. Fernando Domínguez and Jaime de Salas (Tübingen: Max Niemeyer Verlag, 1996), 77-90; Wolfram Drews, "Integration or Exclusion of Judaism in the Later Middle Ages? The Apologetic Strategies of Ramón Llull," in Languages of Love and Hate. Conflict, Communication, and Identity in the Medieval Mediterranean," ed. Sarah Lambert and Helen Nicholson (Turnhout: Brepols, 2011), 239-254; Harvey Hames, "Ramón Llull y su obra polémica contra los judíos," in La controversia judeocristiana en España. (Desde los orígenes hasta el siglo XIII). Homenaje a Domingo Muñoz León, ed. Carlos Del Valle Rodríguez (Madrid: CsIC, 1998), 317-344; Harvey Hames, The Art of Conversion. Christianity and Kabbalah in the Thirteenth Century (Leiden / Boston / Köln: Brill, 200o); Harvey Hames, Ha-Melacha Ha-Ketzara: A Hebrew Translation of Ramon Llull's Ars brevis, "Raimundi Lulli Opera Latina. Supplementum Lullianum" III (Brepols: Turnhout, 2012). "The Kabbalistic sefirot are completely dynamic." Joseph Dan, Ronald Kiener, The Early Kabbalah (Mahwah: Paulist Press, 1986), 13.

21 The idea of God's Dignities represents a departure from the Neoplatonic synthesis, however. According to E.-W. Platzeck, Figure A from Llull's Art, which represents the Divinity, 
The structure of argumentation as described above is completed by the virtues. The disquisitions provided in both speeches should be formulated not only in accordance with the idea of a single God along with His Dignities but also in accordance with the belief that faith, hope, justice, love, prudence, fortitude and temperance are media which lead to God. These latter constitute the theological and cardinal virtues, according to the Latin tradition, and their theological pre-eminence over any other moral virtues during the Middle Ages was entirely consistent with that tradition, especially from the twelfth century onwards. ${ }^{22}$ For this reason, the postulation of these virtues as a locus communis of Christian and Jewish religion is appealing. The fact that these virtues number seven, something explicitly pointed out on two occasions in this part of the work, ${ }^{23}$ might perhaps be of particular significance. It is possible that Llull might have suggested them as another point of contact between both religions, thereby connecting the Christian virtues to the symbolism of the meno$\mathrm{rah}$, the Jewish candelabrum with seven lamps described in Exodus 25:31-40. ${ }^{24}$

has its origins in the thought of Plotinus and the influence of John Scotus Eriugena. See Rubio, "Thought: The Art," and Rubio, "The Natural Realm," in Raimundus Lullus, An Introduction ..., 243-310, here 254-257; 311-349, here 311-312. Neoplatonic synthesis not only had a presence in Jewish and Christian thought, but also in Muslim theology, cf. Dominique Urvoy, Penser l'Islam. Les présupposés islamiques de l'Art" de Lull (Paris: Vrin, 1980), 42-50.

"In the course of the thirteenth century, the theological scheme of the seven principal virtues, which originated in twelfth-century Benedictine writing, came to form part of basic catechetical [Christian] knowledge." Bejczy István, The Cardinal Virtues in the Middle Ages. A Study in Moral Thought from the Fourth to the Fourteenth Century (Leiden: Brill, 2011), 146. Bejczy István offers a detailed analysis of the presence of the cardinal virtues within the Christian tradition. Ambrosius of Milan (340-397) coined the formula uirtutes cardinales or uirtutes principales, for prudence, justice, fortitude and temperance, cf. ibidem, 12. In the Bible, the only explicit reference thereto appears in the Old Testament, in one of the Deuterocanonical books (i.e. books not included in the Hebrew Bible), namely, Wisdom 8:7: "et si iustitiam quis diligit labores huius magnas habent uirtutes sobrietatem enim et sapientiam docet et iustitiam et uirtutem quibus utilius nihil est in uita hominibus." Philo of Alexandria introduced them into his commentaries, though a flourishing Jewish tradition did not take root therefrom, as was the case in Christianity, cf. ibidem, 11, and the Jewish Encyclopedia, http://www.jewishencyclopedia.com/articles/4030-cardinal-virtues. $L A M$, Prologue: "Secunda uero conditio est de diuinis dignitatibus et septem uirtutibus, quibus mediantibus tenditur ad gloriam et obstatur uitiis et peccatis [...]. Tertia autem conditio est de septem uirtutibus antedictis etc."

24 "Make a lampstand of pure gold. Hammer out its base and shaft, and make its flowerlike cups, buds and blossoms of one piece with them [...]. Then make its seven lamps and set them up on it so that they light the space in front of it." 
Neither these virtues nor the Dignities themselves, however, seem to have a precise correspondence within Jewish or Kabbalistic thought. This lack of precision raises the question of Llull's degree of familiarity with Jewish doctrines. As on other occasions, Llull's methods of argumentation, free from quotations or explicit references, as they are, makes it difficult for one to assert with assurance any contact on his part with Kabbalistic works, such as the Zohar, the Sefer Yetzirah or the Sefer ha-Iashar. For this very reason, Harvey Hames considers it likely that Ramon Llull had acquired knowledge of Kabbalistic doctrines chiefly by means of oral teaching within the milieu of the Crown of Aragon, where the Kabbalah, during this period, was more popular than has generally been acknowledged. ${ }^{25}$

In conclusion to these considerations, the prologue to $L A M$ proposes, on the one hand, certain guidelines regarding the development of a correct praxis for inter-religious dialogue, namely, one which is in accordance with justice, order and reasoning. On the other hand, it conceives of the divine Dignities and the seven virtues as being the conditiones whereby to undergird this form of theological and philosophical argumentation. In this sense, Ramon Llull legitimates the dialogue via a common theological as well as soteriological set of conceptions; starting from this solid base, philosophical arguments alone have validity in one's pursuit of agreement between Jewish and Christian sides within the dialogue.

\section{ii) The Doctrinal Discussion: Books I and II}

Once the rules of the dialogue have been established in the prologue, the main part of the book, as set out in Books I and II, is devoted to the discussion of the arrival of the Messiah, this, in fact, being the principal subject of discussion in Jewish-Christian polemics. From its inception, Christian apologetics felt the necessity to justify its faith, both theologically and philosophically, vis-à-vis the Jews, even while Christianity had already achieved political dominance. ${ }^{26}$ In the context of close social cohabitation, many Jews were aware of Christian apologetical arguments concerning the arrival of the Messiah in times past.

25 Besides the esoteric and individualistic branch represented by Abraham Abulafia, one of the authors in this field to whom most attention has been devoted, it is quite plausible to assume the existence of a Kabbalah which was much more inclusive and popular. See Hames, The Art of Conversion ..., 205.

26 "Since Christianity had its origin in the Jewish religion and saw itself as the true heir to biblical Israel, the presence of Jews in its midst was often a source of discomfort." Daniel J. Lasker, Jewish Philosophical Polemics against Christianity in the Middle Ages (Oxford / Portland: The Litttman Library of Jewish Civilization, 2007), 1. 
Refutation of the Christian position, when provided, was usually effected by means of arguments which combined both authoritative texts-such as the Bible, the Talmud or the Midrash — and logical reasoning. This refutation consisted mainly in rejecting the special condition attaching to the Messiah in the eyes of Christians, that is to say, the divinity of Jesus Christ (and, in consequence, rejecting also the Incarnation and the Trinity).

In $L A M$, this criticism is put forward in the first part of the discussion, namely, the first book; the second book, in its turn, contains the demonstration that the Messiah has already arrived as the Son of God.

\section{The Jew's Book}

This book is arranged according to two modes, that is to say, the mode of negation (the non-arrival of the Messiah) [1.1] and the mode of affirmation [1.2]. Negation is the most important mode because here the Jew advances his refutation of the Trinity, the Incarnation and the claim that Jesus Christ was the Messiah announced by the Old Testament, three topics central to the constitution and legitimation of Christianity. The Jew raises his objections to these themes via arguments founded upon the existence of God, the Dignities, the existence and goodness of the virtues and the non-contradiction between these realities, all in line with what had been agreed at the outset. ${ }^{27}$ Summarising the most relevant arguments, the sage sets out the philosophical problems implied by the Trinity, problems which arise since the latter entails composition and superfluous plurality, while in a single God all the perfections of the Dignities can be present. ${ }^{28}$ According to the Jew, however, to argue in favour of the Incarnation involves introducing into God such attributes as finiteness, necessity or, once again, superfluity. To do so also entails contrarieties between certain virtues - between prudence and faith, for instance, or between love and justice. ${ }^{29}$ Acceptance of the Incarnation, contends the Jew,

27 See Euler, “«De adventu Messiae»: Ramón Lulls Beitrag ...," 435-436.

28 LAM, 1.1.1: "Diuinae dignitates sunt in diuina perfectione ita maxime quod unus Deus sufficit in se habere omnes dignitates quas dii infiniti habere possent, quare superfluitas esset plurimos deos esse, postquam unus sufficit omnibus hiis quae possent habere dii infiniti."

$29 L A M, 1.1 .2:$ "Manifestum est diuinas dignitates infinitas esse et habere actus suos infinitos. Si autem Deus foret incarnatus, natura diuina terminata existeret et finita in Incarnatione quam assumpsit, maxime cum illa Incarnatio terminata sit et finita." "Manifestum est diuinam dignitatem nullam in se habere operis superfluitatem nec defectum alicuius rei, nam si intrinsece haberent [sic] opus superfluum aut defectiuum, essent igitur Dei uoluntas, potestas et iustitia contra ipsius bonitatem, magnitudinem, sapientiam et perfectionem. Hoc autem est inconueniens quo significatur manifeste et ostenditur quod si 
leads to conclusions contrary to logic as well as to ones holding unacceptable theological implications. ${ }^{30}$ Finally, the subjugation of the Jewish people and the persistence of perversions and vices in the world indicate clearly that the Messiah has not yet arrived. ${ }^{31}$

These objections bear witness to some of Ramon Llull's typical modes of argumentation, thus, for sure, they do not amount to direct quotations from any individual Jew or Jewish source. Nevertheless, in the context of JewishChristian polemics, it is entirely consistent that such objections should seek to challenge the tenets of Christianity. It seems wholly appropriate, then, to ask whether or not these literary arguments represent real objections raised by Jews, who, being involved in such polemics, insisted on the irrationality of the Christian religion. In this context, Daniel Lasker refers to the Jewish Sefer nizzahon or vikuah, a kind of text particularly influenced by Maimonides' thought, and one which responded to the dogmas of Christian theology by means of philosophical reasoning. ${ }^{32}$

In the analysis of these texts, Lasker finds three principal lines of argument against Christianity:

a) the Trinity implies matter;

b) the divine attributes cannot be Persons;

c) generation implies the negation of unity;

d) syllogistic logic denies the Trinity. ${ }^{33}$

Deus foret incarnatus, illa ergo Incarnatio aut esset superflua aut necessaria dignitatibus diuinis." "[...] est inconueniens et contra cursum naturae Christum esse Deum et hominem quod sic fides et prudentia inter se bene adhaerere nequunt nec conuenire, quia fides credens Deum hominem esse est magis distans ab intelligere quam fides credens Deum nequaquam hominem esse posse."

$30 \quad L A M, 1.1 .2:$ "Nos autem probauimus et certo ordine significauimus Deum non esse incarnatum, quia, si incarnatus esset, sequerentur in tribus conditionibus inconuentientia supradicta, in quibus conditionibus sunt ipsa inconuenientia impossibilia."

$31 \quad L A M, 1.1 .3:$ "Manifestum est iudaeos esse in captiuitate christianorum et sarracenorum, et propter seruitutem in qua detenti sunt patiuntur labores plurimus et paupertates [...]. Si uero Messias aduenerit, nec eius aduentus iudaeis remunerauerit pro laboribus sustentatis, ergo eius aduentus diuinis dignitatibus et humanis uirtutibus contrariatur, conueniens cum peccatis; hoc enim est impossibile [...]. Sed cum ab illa hora qua orbus plasmatus fuit usque nunc fuerit maior multitudo uitiorum quam uirtutum, ergo manifeste denotatur Messiam non uenisse."

32 Cf. Daniel J. Lasker, Jewish Philosophical Polemics, 20-21, 28-32.

33 Lasker, Jewish Philosophical Polemics, 45-104. 
Most of these arguments, therefore, were based upon the incorporeality and immutability of God, His unity, and the illogical consequences entailed by the idea of a God-man. ${ }^{34}$ As regards the arrival of the Messiah, these texts, in general, reject the argument proposed by Christians who assert that the Jews' captivity is the result of Jesus' death; according to these authors, in contrast, the punishment does not stem from the Messiah's death, but rather from their own sins. ${ }^{35}$

It is evident that there is a certain coincidence of ideas between the abovementioned arguments and a number of those presented in the book in which the Jew delivers his speech in $L A M .{ }^{36}$ Furthermore, in both cases philosophical reasoning alone is used to question Christianity. Nevertheless, $L A M$ is written by a Christian; book II will put forward the philosophical response by Ramon Llull to these arguments, a response based upon his personal conception of the Divinity which, as we shall now see, claims to be absolutely rational.

\section{The Christian's Book}

The Christian's book is considerably longer than that of the Jew, and, here, the affirmative mode [2.1] is the most important part, being the first to be voiced. Just like his interlocutor, the Christian sage proceeds to demonstrate the Trinity, the Incarnation and the arrival of the Messiah in times past, as announced in the Old Testament, according to rationes necessariae, based as these are upon the premises explicitly stated in the prologue.

The central argument provided by the Christian to demonstrate the Trinity consists in the idea that there are, of necessity, three elements or required moments in every act, not only in created reality but also in the acts of the divine Creator. ${ }^{37}$ This conception draws on Llull's theory of the correlatives,

34 Lasker, Jewish Philosophical Polemics, 105-134.

35 Lasker, Jewish Philosophical Polemics, 7-8.

36 Cf. Celia López Alcalde, "El Liber de aduentu Messiae de Ramon Llull. Tradición e innovación en el género aduersus Iudaeos," Ámbitos 31 (2014): 59-68, here 67-68.

37 LAM, 2.1.1: "Si autem Deus in essentia et dignitatibus communibus bonificaret et magnificaret se absque distinctione distinctarum personarum, faceret igitur Deus se ipsum et sic essent idem absque ulla distinctione bonificans et bonificatus, magnificans et magnificatus, et caetera. Sed hoc est contradictio qua mediante sequeretur quod uoluntas perfectionem odiret in suo actu et in actibus omnium Dei dignitatum, et diligeret confusionem esse in actibus supradictis." "Nisi uero in Dei entitate fuisset opus intrinsecum priusquam uniuersus orbis crearetur, Deus quidem conueniret cum minoritate actuum in suis dignitatibus priusquam mundus esset, conuenissetque cum maioritate tunc temporis quandoque mundus creatus fuerit ab actibus diuinarum dignitatum operantibus in eodem." See Euler, “«De adventu Messiae»: Ramón Lulls Beitrag ...," 437-438. 
which can be considered a development of Aristotelian physics (matter-formconcordance). ${ }^{38}$ This theory is, in fact, one of the mainstays of Llull's thought from the very beginnings of his literary production. Indeed, the postulation of necessary acts ad intra within God, acts which require a distinction of Persons (paternity, filiation and procession), is his most prominent doctrine intended to demonstrate the Trinity. It plays a key role in $L A M .^{39}$

The doctrine of the Incarnation, on the other hand, is demonstrated by means of several arguments, one of which is epistemological/theological and states that the difficulty of understanding the Incarnation causes the soul to rise towards God, as a result of which the soul comes closer to loving and understanding Him. In this sense, therefore, the lack of clarity present in the Old Testament is well-intentioned and beneficial, affirms the Christian, who asserts the need for an intelligent reading of such texts, i.e. an allegorical interpretation thereof. ${ }^{40}$

38 "En quant a la primera d'aquelles dues triplicitats subratllades es veu que es tracta de l'antiga parella matèria-forma aristotèlica, concebuda—com es pot corroborar llegint qualsevol de les explicacions lul-lianes d'aquesta doctrina-hilemòrficament, a la faisó d'Avicebron i dels augustinians, però convertida en semblança trinitària afegint-hi el tercer terme concordansa" ["As regards the first of these two triads to which emphasis has been given, one can see that it concerns the ancient Aristotelian pairing of matter and form, conceived — as can be confirmed by reading any of the Lullian explanations regarding this doctrine-hylomorphically, in the manner of Avicebron and the Augustinians, although turned into a likeness of the Trinity by adding to it the third term 'concordance'"], Robert Pring-Mill, El microcosmos lul.lià (Palma de Mallorca: Editorial Moll, 1961), 140.

$39 L A M$, 2.1.1: "Nisi uero in Dei entitate fuisset opus intrinsecum priusquam uniuersus orbis crearetur, Deus quidem conueniret cum minoritate actuum in suis dignitatibus priusquam mundus esset."

$40 \quad L A M, 2.1 .2:$ "Ratio autem quare Deus non explanauit clarius aduentum domini Ihesu Christi per prophetas secundum litteralem explanationem fuit haec, uidelicet ut humanus intellectus occasionem haberet se exaltandi in expositione morali et spirituali." Euler compares this fragment with that from the Liber praedicationis contra Iudaeos in which an allegorical reading is clearly espoused, and "rusticitas" and "ruditas" are attributed to the Jews, because they do not know how to read the biblical texts correctly. See Euler, "«De adventu Messiae»: Ramón Lulls Beitrag ...," 438. This is the same idea, in fact, as that defended by the Jew Maimonides in the Guide for the Perplexed, when he says: "This work has also a second object in view. It seeks to explain certain obscure figures which occur in the Prophets, and are not distinctly characterized as being figures. Ignorant and superficial readers take them in a literal, not in a figurative sense." Translation by Michael Friedländer (London: Routledge and Kegan Paul Ltd., 1904), Prefatory Remarks, 3. The Dominican Ramon Martí follows this line as well when he says that the Jews do not interpret their own texts properly: "Sciendum autem quod quotienscumque Talmud offert nobis aliquam auctoritatem propheticam exponens eam de Messia, uel de illis quae ad 
Of lesser relevance, however, is the argument based upon the concordance between the Dignities and the virtues in Christ, which likewise aims to demonstrate the Incarnation. ${ }^{41}$

Finally, in order to prove that the Messiah has already arrived, the Christian replies to the Jew's objections via an appeal to Christianity's chief argument in this respect, namely, that the suffering and captivity of the Jewish people has been perpetuated on account of the fact that they have failed to accept the message of Christianity. ${ }^{42}$ Thus, they persist in their error, Llull insists, by considering that the Messiah announced in the Old Testament is a political liberator rather than a spiritual one (i.e. one who liberates them from original sin) ${ }^{43}$ The adhesion of Ramon Llull to this Christological doctrine in $L A M$ is a further proof of the fact that the work belongs to an early phase of his literary production: in subsequent works, namely, from ca. 1285 onwards (starting with the Liber de quattuordecim articulis catholicae fidei Romanae Ecclesiae sacrosanctae), on the other hand, the arrival of the Messiah will be related to the sublimation of Creation and man, rather than to redemption from original sin. ${ }^{44}$

Messiam pertinere noscuntur, si bene eam exposuerit, admittenda est [...]. Si autem, ut frequentius facit, fabulose aut male ipsam exposuerit, abicienda est tunc eius expositio, auctoritate retenta." Ramon Martí, Capistrum Iudaeorum, ed. Adolfo Robles (Würzburg / Altenberge: Echter / Telos, 1990), II, Prima nequitia, 6, 1-7.

$41 \quad L A M$, 2.1.2: "Quoniam si Deus sit homo et homo sit Deus absque contrarietate diuinarum dignitatum et humanarum uirtutum, ergo potest inde esse maioritas actuum inter diuinas dignitates et humanas uirtutes, et quoniam maior concordantia esse potest in esse Dei hominis et hominis Dei, ergo designatur in maiori concordantia Deum uoluisse hominem esse."

$L A M$, 2.1.3: "Sed per hanc etiam captiuitatem in qua sunt, denotatur iudaeos nunc esse culpabiliores erga diuinas dignitates, atque magis egentes uirtutibus quam fuerunt patres eorum in tempore dictarum duarum captiuitatum [...]. Hoc autem est inconueniens, quo significatur iudaeos esse in captiuitate, eo quia per negationem aduentui Messiae contrariantur, cui nequaquam essent contrarii, si uenturus esset."

$43 L A M, 2.1 .3$ : "Finalis quidem intentio in qua iudaei aduentum Messiae desiderant est secundum hanc beatitudinem terrenam, et secundum deliberationem corporum a captiuitate. Christiani uero finalem intentionem habent olim uenisse Messiam ad deliberationem humani generis a captiuitate intellectuali et a peccato originali, praestando spiritualem gloriam, et ad conferendum inter Deum et hominem maiorem concordantiam et pacem." About Llull's Christology, see Robert D. Hughes, The Christology of Ramon Llull in the Light of his Ars magna (Ph. D. thesis, Lancaster University, 2002); and, among other articles, Robert D. Hughes, "Speculum, Similitude, and Signification: the Incarnation as Exemplary and Proportionate Sign in the Arts of Ramon Llull," Studia Lulliana 45-46 (2005-6):3-37; Robert D. Hughes, "Ramon Llull's Gradualist Solution to the Hypothetical Question: «Utrum Deus fuisset incarnatus, si non fuisset originale peccatum?»," Studia Lulliana 53 


\section{iii) Epilogue}

In order to conclude the dialogue, $L A M$ provides an epilogue which, despite its brevity, is interesting for several reasons. We are first given what seems to be the author's own position as regards the success of the dialogue itself. In fact, Ramon Llull seems to be aware of the difficulty of achieving agreement in religious matters, where adherence to one's own set of beliefs often invalidates the possibility of rational judgment and agreement. It is from such an awareness, then, that the Christian sage proposes to his Jewish counterpart the intellectual exercise of considering the Christian doctrine as a hypothesis, in order to subject it to discussion, on the grounds that only once it has been understood will he be able to either accept or reject it. ${ }^{45}$ As a consequence of such a proposal, the Christian asks if, for the time being, they may leave to one side any preconceptions with regard to understanding and move towards a judgement only subsequently. Indeed, according to Ramon Llull, the result of such a procedure would be an inevitable conversion to Christianity by way of necessary reasons, provided as these are by his Art, a system which had no other mission than to convince non-Christians of the truth of the Christian faith, and to achieve their conversion. ${ }^{46}$

Nevertheless, this book does not present any process of conversion at all, and the dialogue is close to being perpetuated indefinitely in the form of a list of arguments, which, though they are not sufficient to give rise to consensus, bring both sages gradually closer to the truth regarding the arrival of

(2013): 67-103; Fernando Domínguez, "El discurso luliano De homine en el contexto antropológico coetáneo," in Què és l'home? Reflexions antropològiques a la Corona d'Aragó durant l'Edat Mitjana, ed. Josep Corcó, Alexander Fidora, Josep Olives Puig, and Jordi Pardo Pastor (Cambrils: Prohom Edicions, 2004), 101-127; Euler, “«De adventu Messiae»: Ramón Lulls Beitrag ...," 439.

LAM, Epilogue: "Christianus itaque expediens suum librum terminauit exhortans iudaeum dulcissimis sermonibus ut conuersus sanctam fidem catholicam acceptaret, et, si dubitaret eam suscipere, supponat ipsam fidem catholicam esse ueram aut falsam, quia naturae est intellectus se exaltare ad inquirendum uerum et falsum per suppositionem ueri et falsi. Cum autem intellectus per fidem non supponit uerum aut falsum, non habet cum quo generare possit suum intelligere in habitum per quem transit de potentia in actu."

46 See Rubio, "Thought: The Art," in Raimundus Lullus, An Introduction ..., 246: "However, in order to be able to make correct use of the Art, it is necessary to start out by having a predisposition to accept the truth, even if this means renouncing one's own faith should this be revealed to be false. To put this another way, one's approach to the Art must be unencumbered by any form of prejudice and one must be fully prepared to accept the truth as the only valid conclusion, whatever this might be." 
the Messiah. ${ }^{47}$ This lack of agreement, in fact, does not seem to affect Llull's appreciation of dialogical praxis. Such non-agreement, in contrast, emphasises the advantages of its own incidental effects: in itself the dialogue is a semita ueritatis which shows the minimal differences between Jews and Christians. The simple fact of talking, as can be deduced from this work by Ramon Llull, brings Jews and Christians closer together and has the power to prevent quarrels, as well as segregation, between each party — a shameful and real situation whose consideration, in the prologue, served to justify the dialogue, as well as the work itself.

\subsection{Ramon Llull and the Jewish Milieu}

If one accepts this conclusion, it would seem coherent likewise to affirm that, when composing the work, Ramon Llull considered dialogue between Christians and Jews to be appropriate and beneficial within the context of religious cohabitation, a situation which prevailed in Llull's homeland during the thirteenth century. ${ }^{48}$ This was a century of major change in Majorca; Almoravids and Almohads had ruled there until 1229, when Christians took possession of the island. Despite the fact that the majority of the population was Muslim, there was also a considerable Jewish community. It is possible that this community had not been treated particularly well by the Almohad government, more fundamentalist as it was than its Almoravid predecessor, and this fact would have favoured the Jews' support of the Christian conquest, and, in return, the concession of privileges and protection by James I. Politically the Jews were considered much less dangerous than the Muslims, for which reason the king allowed them to live according to their own laws and under their own administration, while also affording them other advantages. ${ }^{49}$ Such a degree of

$47 \quad L A M$, Epilogue: "Ambo longanimiter cogitarunt inter se ad inuicem alter alterum speculantes, altero alterum suadente, ut in lege sua conuerti deuotae dignaretur [...]. In quanto fortius disputabant inquirentes expresse ueritatem percipere, in tanto fortius apparebat in aduentu Messiae ueritas manifesta."

48 "Together with the Latin Christians, the Jews and Muslims formed part-although in different ways—of the island's population as it stood in the thirteenth century and among which Llull was raised." Domínguez and Gayà, "Life," in Raimundus Lullus, An Introduction ..., 19.

49 Cf. David Abulafia, A Mediterranean Emporium: The Catalan Kingdom of Majorca (Cambridge: Cambridge University Press, 1994), 78-80. 
autonomy contributed to the fact that, during the second part of the thirteenth century, the Jewish community experienced a "golden age."

At the social level, however, the number of tensions between Christians and Jews progressively increased. Thus, from the fourteenth century onwards, the monarchs adopted a less favourable position towards the latter. Famine and Black Death were some of the causes alleged for a strong social antagonism in the Crown of Aragon, which blamed Jews for being the source of these desasters. In Majorca, the established power decided to isolate them within the Call (or Jewish Quarter) in 1303, and ultimately eliminate their privileges and freedoms ${ }^{51}$ As is well known, this process terminated in the mass conversions of $1435 .^{52}$

This unfortunate dénouement, however, predates by a considerable margin the composition of $L A M$, a work which, in fact, seems to point to a much less tense social climate. Although not a great deal of information is available concerning Llull's relations with the Jewish community, we are nevertheless aware of the presence of Jews in his homeland, on the one hand, and, as documentary evidence informs us, on the other, that Llull requested and received royal licence to preach in mosques and synagogues. ${ }^{53}$ Moreover, it is very likely that Ramon Llull, who was always a well-connected figure, maintained contact with distinguished Jews, not only in Majorca but also in the Crown of Aragon. ${ }^{54}$ Lastly, Ramon Llull left Majorca in ca. 1275 so as to take up residence at Montpellier, a city whose cultural development was attributable principally

5o There were also many Jews that went to Majorca to support the conquest. See Urvoy, Penser l'Islam, 92-93.

$5^{1} \quad$ Urvoy, Penser l'Islam, 83-88.

$5^{2}$ It was not the end of a wider and terrible phenomenon. In the opinion of some scholars, most of present day prejudices and violent attitudes against Judaism were formed in the Middle Ages. Cf. David Nirenberg, "Introduction," in Communities of violence. Persecution of Minorities in the Middle Ages (Princeton NY: Princeton University Press, 1996), 4-17. According to Nirenberg's study, focused on the Crown of Aragon during the fourteenth century, anti-Judaism was not the outcome of an irrational feeling of people but something oriented and used by the established power.

53 Cf. Antoni Rubió i Lluch, Documents per l'història de la cultura catalana mig-eval (Barcelona: Institut d'Estudis Catalans, 1908), I, 13-14.

54 It is possible that he dedicated one of his works to some of these notable Jews; in the inventory of Joan Bonllavi's books there is a work attributed to Ramon Llull whose incipit states: "Als savis jueus de Barcelona mestre Abram Denanet e mestre Aron e mestre Ben Jua Salamon i altres savis que son en la aljama, Ramon Lull salut." There have been several attempts to identify these masters, cf. Harvey Hames, The Art of Conversion..., 109-112. One of their number could have been Salomon Ibn Adret, leader of the Jewish community in Barcelona, "the foremost rabbinic authority of his day," Yitzhak Baer, A History of 
to the presence of Jews who there engaged in intellectual labours, such as the translation of learned works. ${ }^{55}$

In addition to the foregoing biographical information, the conceptions and positions that, in a more or less explicit way, our author expresses in his books, assist us in defining with greater exactitude the relations Ramon Llull maintained with Jews. While bearing in mind that the principal aim of all his work was the conversion of "infidels," many scholars have also placed paradoxical emphasis upon his tolerance in matters religious. This argument is based chiefly upon the testimony borne by the Llibre del gentil e dels tres savis, in which three sages (a Christian, a Jew and a Muslim) make their appearance, and discuss their respective faiths in a polite and respectful way. $L A M$, likewise, exhibits similarly respectful manners as those displayed in the Llibre del gentil. It is within this context that Harvey Hames analyses the ambiguity of Llull's conduct, given that the latter, despite his aforesaid tolerant approach, also characterises the Jews as being a people who lack the capacity to reason, and who, because of this, are in fact inferior to the Saracens, which latter were more inclined towards philosophy, on account of their intellectual nature. ${ }^{56}$ This ambiguity has led some scholars to state that, in reality, Llull's tolerance is only fictional, that is to say, used merely for proselytising purposes. ${ }^{57}$ According to Hames, however, the explanation of this apparent contradiction could be that Ramon Llull distinguished, in effect, between the ordinary-i.e. uneducated-Jewish people and those learned among them, with which latter dialogue was very much possible and appropriate. ${ }^{58}$ Whatever the case may be, the differences in his approach may also point to an evolution on his part towards the use of more effective and aggressive methods within those works of his which were aimed at the conversion of "infideles."

the Jews in Christian Spain (Philadelphia: Jewish Publication Society of America, 1961), I, 260 .

Cf. Joseph Shatzmiller, "Contacts et échanges entre savants juifs et chrétiens à Montpellier vers 1300," Juifs et Judaïsme de Languedoc. Cahiers de Fanjeaux 12 (1977): 337-344. Near Montpellier, in Lunel, we find the Tibbonides dynasty, famous for their translations from Arabic into Hebrew. See Urvoy, Penser l'Islam, 92-97.

$5^{6}$ "Iudaei sunt homines sine scientia et quando catholicus disputat cum ipsis rationabiliter, non intelligunt rationes." Ramon Llull, Liber de acquisitione terrae sanctae, ed. Eugène Kamar in "Projet de Raymond Lull De acquisitione Terrae Sanctae. Introduction et édition critique du texte," Studia Orientalia Christiana Collectanea 6 (1961): 103-131, here 121.

57 Yitzhak Baer, for example, has pointed to the fact that Llull's tolerance was only literary, while Jeremy Cohen has also lent support to this view, see Hames, The Art of Conversion ..., $85^{-86 .}$

$5^{8}$ Hames, The Art of Conversion ..., 89. 


\subsection{Mendicants and Disputations}

Ramon Llull lived and composed $L A M$ at a time when the concept of mission had acquired a central position among the interests of the Church. The mendicant orders had taken on the mission of converting non-Christians to Christianity, ${ }^{59}$ using the most efficacious methods and strategies to achieve this goal, methods such as, for example, the employment of their interlocutors' own language, ${ }^{60}$ and reference to the latter's authoritative texts. ${ }^{61}$ In the case of the missions with respect to Jews, this approach was not restricted to the use of the Bible; in fact, Christians also quoted the Talmud and Midrash, to show that even those texts proclaimed the Christian truth. This new form of polemics is made evident in the well-known Jewish-Christian disputations of the thirteenth century: first in Paris, in 1240, and later in Barcelona, in 1263, the latter being conducted between Pau Crestià (Paul Christian) and Moses Nahmanides.

The disputation at Barcelona is important for understanding a work such as $L A M$, since both belong to the same intellectual milieu. Two Dominicans, who were very influential not only upon Llull's missionising but also upon his way of conceiving his approach towards the Jews, can be linked-either physically or intellectually — with this disputation. One such, who actually took part in the dispute, was Ramon de Penyafort, "maxime frater de ordine praedicatorum," an acquaintance of Ramon Llull, according to the latter's biography. ${ }^{62}$

59 "The major changes in anti-Jewish polemic, however, came only in the thirteenth century with the inquisitorial and missionary efforts of Dominican and Franciscan friars." Jeremy Cohen, The Friars and the Jews. The Evolution of Medieval Anti-Judaism (Ithaca / London: Cornell University Press, 1982), $32 \mathrm{ff}$.

6o "The Dominicans were spurred on to learn languages for missionary purposes." Alfonso Maierù, "Dominican Studia in Spain," in Philosophy and Theology in the 'Studia' of the Religious Orders and at Papal and Royal Courts, ed. Kent Emery Jr., William J. Courtenay, and Stephen M. Metzger (Turnhout: Brepols, 2012), 3-31, here 16.

61 Within the context of the polemics between Muslims and Christians, this task had its roots in the translations of the Koran into Latin, the first of these occurring in the midtwelfth century, cf. James Kritzeck, Peter the Venerable and Islam (New Jersey: Princeton University Press, 1964); José Martínez Gázquez, "Finalidad de la primera traducción latina del Corán," in Musulmanes y cristianos en Hispania durante las conquistas de los siglos XII y XIII, ed. José Martínez Gázquez and Miquel Barceló (Bellaterra: Universitat Autònoma de Barcelona, 2005), 71-78; Thomas E. Burman, Reading the Qur'an in Latin Christendom, 1140-1560 (Philadelphia: University of Pennsylvania Press, 2007).

62 Thus, according to his biography, the Vita coaetanea, Llull asked Ramon de Penyafort for orientation in missionary matters: "Completa ergo peregrinatione sua predicta, parauit iter arripere Parisius, causa discendi ibi grammaticam et aliquam aliam scientiam, suo proposito congruam. Sed ab hoc itinere parentes et amici sui, et maxime frater 
The other Dominican was Ramon Martí (Raymond Martini), whose origins lay in the missionary school established by Ramon de Penyafort, and who was familiar with the Hebrew language and the Jewish authoritative texts. ${ }^{63} \mathrm{He}$ is considered to be, in fact, one of the most important authors in the field of religious polemics.

One can immediately appreciate that $L A M$, much more than the Llibre del gentil, ${ }^{64}$ is closely related to this polemical context promoted and overseen by the Dominicans: its subject matter, shared by the Disputation of Barcelona, as well as by the Capistrum Iudaeorum (1267) and the Pugio fidei (1280) by Ramon Martí, gives a clear indication of this fact. ${ }^{65}$

Nevertheless, $L A M$ marks a point of rupture with respect to the methods of the Dominicans, who made extensive use of auctoritates both to create and to bolster their lines of argument. ${ }^{66}$ From the very outset, however, our Majorcan

Raimundus de ordine praedicatorum [...] suis persuasionibus et consiliis diuerterunt, et eum ad ciuitatem suam, Maioricarum scilicet, redire fecerunt." Ramon Llull, Vita coaetanea, "Raimundi Lulli Opera Latina" viıI, ed. Hermogenes Harada (Turnhout: Brepols, 1980), 278.

63 "We find a studium ebraicum in Barcelona, in which Ramón Martí, who for some time was a member of a commission appointed to examine writings in Hebrew, taught." Maierù, "Dominican Studia in Spain," 17.

64 Cf. Ramon Sugranyes de Franch, "Le «livre du Gentil et des trois sages» de Raymond Lulle," Juifs et Judaïsme de Languedoc. Cahiers de Fanjeaux 12 (1977): 319-335, here 332.

65 For this disputation, see among others, Gilbert Dahan, La polémique chrétienne contre le Judaïsme au Moyen Âge (Paris: Albin Michel, 1991); Robert Chazan, Barcelona and Beyond. The Disputation of 1263 and Its Aftermath (Berkeley: University of California Press, 1992).

66 According to Ryan Szpiech, it is possible to detect at least five instances in which Ramon Llull criticised Ramon Martí, cf., Ryan Szpiech, Conversion and Narrative. Reading and Religious Authority in Medieval Polemic (Philadelphia: University of Pennsylvania Press, 2013), 135. Among these, we come across a putative reference to Martí in the Liber de acquisitione terrae sanctae (1309), in which Llull narrates that, during a discussion with the king of Tunis, a particular Christian friar, "bene in arabico litteratus," stated that "fides christianorum non potest probari, sed ecce symbolum in arabico expositum, credas ipsum." The king, however, goes on to reproach the friar for not having demonstrated the Christian faith to him and hence for having left him without any religion. (Ed. Eugène Kamar, Projet de Raymond Lull De acquisitione Terrae Sanctae ..., 126). It was Éphrem Longpré who was the first to identify this friar with Ramon Martí. See Éphrem Longpré, “Le B. Raymond Lulle et Raymond Martí, O.P.," Estudios Lulianos 13 (1969): 197200. Nevertheless, as Szpiech notes, recent studies have cast doubt upon this attribution, due to the lack of correspondence between the actual figure of our Dominican and the characterisation given in Llull's works, see Josep Maria Ruiz Simon, L'Art de Ramon Llull i la teoria escolàstica de la ciència (Barcelona: Quaderns Crema, 1999), 361-362. In turn, Alexander Fidora admits the possibility of a superficial knowledge of Ramon Martí by 
author aims to employ reason alone in his missionary tasks. His Art, in fact, is an explanatory system intended in itself to yield all the elements necessary for the demonstration of truth, and to secure conversions to Christianity. ${ }^{67}$

\section{4}

\section{Tradition and Innovation in $L A M$}

\subsection{Continuity with the Literature ad Iudaeos}

This is not the place to list and describe the vast number of examples which go to form the medieval literature ad Iudaeos. ${ }^{68}$ This literature is as old as Christianity itself, a religion that would soon proclaim, vis-à-vis Judaism, its own specificity and superiority inasmuch as it claimed to be the legitimate heir to the Mosaic Law. The examples of this genre, therefore, have fluctuated between a more tolerant attitude, which considered the Jewish people to be the predecessors to Christian truth, and a less tolerant one, which reproached the same for not having recognised Jesus Christ and for having persevered in their error, despite the efforts of Christians (via the New Testament, the Fathers and, in general, the whole Church) to lead them towards the truth. The influential thought of Augustine of Hippo represented the inspiration for the first attitude, since he underlined the continuity between the Jewish

Llull, who used him as a "counterexample" to his own work and system. See also Alexander Fidora, "Ramon Martí in Context: The Influence of the Pugio fidei on Ramon Llull, Arnau de Vilanova and Francesc Eiximenis," Recherches de Théologie et Philosophie Médiévales 79 (2012): 373-397, here $376-381$.

67 "Il n'est donc pas impossible que la dispute de Barcelone, tout en restant étrangère à la technique de la pensée lulliane [...], ait néanmoins servi de «cause occasionnelle » à ce passage du seuil décisif : le choix d'une méthode qui s'efforce d'englober les présupposés de tous les participants." Urvoy, Penser l'Islam, 118.

68 Cf., among others, the following studies: A. Lukyn Williams, Adversus Iudaeos. A Bird'seye View of Christian Apologiae until the Renaissance (Cambridge: Cambridge University Press, 1935; Josep Hernando (ed.), "Tractatus aduersus Iudaeos. Un tratado anónimo de polémica antjudía (S. XIII)," Acta historica et archaeologica mediaevalia 7-8 (1986): 9-77; Gilbert Dahan, La polémique chrétienne contre le Judaïsme au Moyen Âge (Paris: Albin Michel, 1991); John Tolan, Petrus Alfonsi and his Medieval Readers (Gainesville: University Press of Florida, 1993); Leopold Lucas, The Conflict between Christianity and Judaism. A Contribution to the History of the Jews in the Fourth Century (Warminster: Aris and Phillips, 1993); Hanne Trauner-Kromann, Shield and Sword (Tübingen: J.C.B. Mohr, 1993); Samuel Krauss, William Horbury, The Jewish-Christian Controversy from the Earliest Times to 1789, vol. I (Tübingen: J.C.B. Mohr, 1995); Jeremy Cohen, Living Letters of the Law. Ideas of the Jew in Medieval Christianity (Los Angeles: University of California Press, 1999); William Horbury, Messianism Among Jews and Christians (London: T and T Clark, 2003). 
people and their Christian counterparts. The attitude which manifested greater intransigeance, however, would come to feature as a more prominent phenomenon throughout the Middle Ages. Anti-Judaism was something more than mere religious conflict, and the socio-economic situation made the cohabitation between Jews and Christians more awkward. As is well known, this tense situation ultimately resulted in expulsions, forced conversions and subsequent accusations of crypto-Judaism during the closing years of the Middle Ages and the opening ones of the modern period. ${ }^{69}$

Despite its quite exceptional conciliatory nature, and some of its specific features - which we shall see below— LAM should be considered to be yet another example of this genre ad Iudaeos. This literature was not always actually directed at converting "infidels"; sometimes, in fact, this kind of text was aimed at strengthening the faith of the Christians themselves, in order to prevent heresy. ${ }^{70}$ This does not seem to be the case with $L A M$, however, since it appears to take into account genuine objections towards Christianity.

Furthermore, its right to be considered part of this large group of texts can likewise be established on account of the following features, which concern its content and form, respectively:

\section{a) Subjects of discussion: Trinity, Incarnation and the arrival of the Messiah.}

These subjects coincide with those dealt with in other contemporary texts ad Iudaeos. Thus, in his Capistrum Iudaeorum Ramon Martí examines the same subject matter. Notwithstanding this fact, both texts display important differences as regards their methods of argumentation. As we have already mentioned, Ramon Llull prefers his arguments to be without citation from or reference to authorities, not even biblical ones. Ramon Martí represents the other side of this coin, making abundant use of quotations from the Bible, the Fathers, the Talmud and the Midrash to demonstrate the errors of the Jews and the truth the Christian religion offers. The method of argument employed in $L A M$, namely, arguments according to reason alone, is a specific feature that marks out this work from all of the other texts ad Iudaeos, since most of these latter lent support to their arguments by recourse to authoritative texts. ${ }^{71}$ The difficulty of presenting proofs of the Trinity or the Incarnation by means of rational procedures, as well as Llull's strict adherence to the Church, which

69 See note $5^{2}$.

70 Many times these Christian texts were not against Jews, but "to develop their own emerging theology." Lasker, Jewish Philosophical Polemics, xx.

71 See the study by Moisés Orfali, Talmud y Cristianismo (Barcelona: Editorial Riopiedras, 1998). 
was suspicious of any abuse in philosophy, can easily explain this manner of approaching such topics.

Ramon Llull would follow these more conventional methods in the Liber praedicationis contra Iudaeos of 1305, a homiletic book in which Christian superiority is given as a fact. Here, his attitude towards the Jewish people has changed, and he even describes them as an ignorant people. ${ }^{72}$ The work is consists of fifty two sermons, and the arguments are a combination of reasoning and quotation from the Old Testament. Ramon Llull finally came closer, in this book, therefore, to the customary apologetical methods practised during that particular period.

\section{b) Dialogical style.}

The recreation of a dialogue between two or more characters was a common way of expounding the content in this kind of text. Medieval authors, such as Peter Alfonsi, Peter Abelard, Alfonso of Valladolid or Gilbert Crispin used a dialogical style to articulate their defence of Christianity. As is the case in Llull's work, the characters involved were frequently a Jewish sage and his Christian counterpart. It is possible that these works were inspired by actual dialectical disputes, but it might also be true that, in contrast, such actual disputes were inspired by the literary genre of the disputatio, especially if one takes into account the fact that the documented disputes occurred only subsequently to an already well-established literary tradition.

As far as dialogical style is concerned, Armand Llinarès has distinguished two subgroups within the religious dialogues elaborated by Ramon Llull: first, inclusive dialogues (as indicated by Colomer, to this group belong the Llibre del gentil and $L A M$, among others) $;^{73}$ and, second, controversies, which aim to demonstrate the superiority of the Catholic religion (included here are the Disputació dels cinc savis, the Liber praedicationis contra Iudaeos and the Disputatio Raimundi Christiani et Homeri Saraceni). ${ }^{74}$ According to Llinarès, Ramon Llull began his dialogical practice in the strict sense prior to his

72 See de la Cruz, "The Human Realm," 449.

73 See Armand Llinarès, Raymond Lulle, philosophe de l'action (Paris: Presses Universitaires de France, 1963), 269-288. Cf. Roger Friedlein, Der Dialog bei Ramon Llull. Literarische Gestaltung als apologetische Strategie (Tübingen: Max Niemeyer, 2004), 49ff., and Eusebi Colomer i Pous, "El diàleg interreligiós en Ramon Llull," in El pensament als pä̈sos catalans durant l'Edat Mitjana i el Renaixement (Barcelona: Institut d'Estudis Catalans / Publicacions de l'Abadia de Montserrat, 1997), 113-179, here 152.

74 Eusebi Colomer has, in turn, suggested an intermediate group of texts, namely, apologies; according to him, the Disputació dels cinc savis, strictly speaking, belongs to this group. See Colomer i Pous, "El diàleg interreligiós en Ramon Llull," 152-153. 
encounters with North-African Muslims; it was only afterwards that he came to develop a more intransigeant attitude towards the "infidels."75

Since $L A M$ and the Llibre del gentil ${ }^{76}$ were both composed during the same period, the two works can be considered to exist in close relation to each other, particularly if one takes into account: a) the polite manners exhibited by the respective speakers therein; ${ }^{77} \mathrm{~b}$ ) the fictional settings thereof, i.e. both being loci amoeni; and c) their endings, which both lack an explicit resolution to the disputation and fail to reveal, in a manner we might call clear, the actual position adopted by their author. Nevertheless, there are other features which reveal marked differences: the dialogue of the Llibre del gentil is addressed to someone who has no Law and thus no knowledge of God, namely, to a gentile rather than to a Jew or a Muslim. The arguments employed by both serve to connect the three religions in a certain manner, religions which share a very similar feeling of religiosity, as well as faith in a single God; however, the Gentil is composed in accordance with a far more complex symbolism, and reveals a more comprehensive "cultural conscience," this being attributable to its descriptions, which are not solely theological and philosophical but also concrete and illustrative of customs (i.e. Muslim and Jewish traditional practices). ${ }^{78}$ $L A M$, in contrast, reveals scant rhetorical adornment. It constitutes, in sum, a dialogue between two characters in which there is scarcely a modicum of theatricality, and wherein the author's attention is focused upon these characters' philosophical argumentation in particular.

75 Nevertheless, according to Llinarès, such instransigeance manifests itself merely at a confessional level: "Il ne manifeste aucune haine contre eux; sa seule prévention est d'ordre spirituel." Llinarès, Raymond Lulle, philosophe de l'action, 282. See as well, Mark D. Johnston, "Disputation” in idem, The Spiritual Logic of Ramon Llull (Oxford: Clarendon Press, 1987), 134-145.

76 Ramon Llull, Llibre del gentil e dels tres savis, "Nova Edició de les Obres de Ramon Llull" II, ed. Anthony Bonner (Palma de Mallorca: Patronat Ramon Llull, 2001). Recent Latin editions: Ramon Llull, Liber de gentili et tribus sapientibus, "Raimundi Lulli Opera latina" Xxxvi, ed. Óscar de la Cruz Palma (Turnhout: Brepols, 2015); Libro del gentily los tres sabios, edition taken from a base manuscript, together with a Spanish translation, by Matilde Conde (Madrid: BAC / UNED, 2007).

77 This respectful atmosphere also characterises the Liber tartari et christiani and the Disputació dels cinc savis. Moreover, the incipit from the library of Joan Bonllavi would confirm this tolerant approach to the Jews, cf. note 54 .

78 See de la Cruz, "The Human Realm," 437. 


\subsection{Continuity with the Art}

According to the well-known account offered by the Vita coaetanea, Ramon Llull received from God the inspiration to write "the best book in the world."79 This book is dispersed across almost his entire literary oeuvre, an oeuvre in which he developed his Art as a system of thought. ${ }^{80}$ Even though LAM is not an "artistic" work - as the Ars compendiosa, Ars generalis, Ars breuis, etc., in fact, are - it nevertheless also reveals certain features which are considered to be characteristic of Llull's thought:

The divine Dignities. As has been pointed out, the theory of the Dignities plays a key role in our work. According to Llull, the Dignities are realities which connect Creator and creation. This theory also, however, represents a link between Jews and Christians. Llull's constant efforts to systematise and synthesise result in the initial list containing sixteen Dignities being reduced to nine in his later works. ${ }^{81}$

The theory of the correlatives. This theory, together with that of the Dignities, undergirds Ramon Llull's theological standpoint. ${ }^{82}$ It consists in a dynamic conception of reality founded upon three co-essential elements, which refer to matter/potency, form/act and concordance/object, respectively. In $L A M$, this theory explains the acts ad intra in God, viz. the Trinity, as previously mentioned.

Elemental exemplarism and locus amoenus. Elemental exemplarism undergirds the correlative theory, and is associated with contemporary physics, which departed from the Aristotelian De generatione et corruptione. The idea of the elements and their qualities served as an inspiration for Llull's correlative theory, enabling him to explain the relations and the possibility of acts within the divine Dignities themselves. This theory does not enjoy the same presence in $L A M$ as it does in Llull's other books; ${ }^{83}$ nevertheless, it appears precisely

79 Ramon Llull, Vita coaetanea ..., 259-309.

80 About the development of Llull's Ars, see the study by Bonner, The Art and Logic.

81 See note 5 .

82 See Bonner, The Art and Logic, 284: "Very soon, the dignities become inseparable from their activity." This activity is explained by the Trinitarian/correlative structure present in everything, including God: "Todo lo que se precie de ser, es en la dinámica estructura correlativa." Jordi Gayà, La teoría luliana de los correlativos (Palma de Mallorca: Impresos Lope, 1979), 220. Gayà's study analyses the genesis and development of this Lullian theory.

83 This theory enjoys a marked presence from the time of the Ars demonstratiua onwards, see Rubio, "Thought: The Art," 261. Cf. Pring-Mill, Estudis sobre Ramon Llull, 252. The 
in the context of acts ad intra. ${ }^{84}$ Robert D. F. Pring-Mill considered that the assumption of this physical model was highly important for Llull's methods of argumentation in virtue of that model's demonstrative power; this is certainly true in the case of $L A M .85$

There is, on a less obvious level, another possible reference to this theoretical framework, namely, the bucolic scene which provides the setting for the dialogue between the two sages. ${ }^{86}$ According to Frances A. Yates, this bucolic scene plays a role in many of Llull's works: it is implicitly proposed as being the best place for the intellect to understand reality. Yates thus suggests that the trees which appear in those of Llull's works which are aimed at securing conversions are related to such elemental exemplarism. More recently, Lola Badia discusses Llull's recreation of the locus amoenus in the context of his rethorical strategies. ${ }^{87}$

topic is analysed in particular in the articles by Frances A. Yates, "The Art of Ramon Lull: An Approach to It Through Lull's Theory of the Elements," Journal of the Warburg and Courtauld Institutes 17/2 (1954): 115-173; and Charles Lohr, "Ramon Llull's Theory of the Continuous and Discrete," in Late Medieval and Early Modern Corpuscular Matter Theories, ed. Christoph Lüthy, John E. Murdoch, and William R. Newman (Leiden / Boston / Köln: Brill, 2001), 75-89.

$84 L A M, 2.1 .1$ " "Certum et euidens est secundum cursum naturalem quod ignis simplex potestatem habet in igne composito, nam praeter illam potestatem ignis simplex generare nequiret ex prima materia ignem compositum in materia secunda. Vnde si ignis in suamet natura potestatem habet generandi alterum ignem, et iste actus sit ei prius et naturalior quam ipse actus quem ignis habet in aere et in caeteris elementis, de necessitate sequitur quod Deus in actu diuinarum dignitatum potestatem habeat in Deo et potestatem in potestate."

$85 L A M, 2.1 .1$ : "Ignis et caetera elementa non habent potestatem habendi actum in se ipsis nec unum in alterum absque generatione et processione et caetera; ea per quae maxime species existunt in conseruatione sunt generatio et processio, quibus earum indiuidua perueniunt in esse, atque propter priuationem generationis et processionis perueniunt in corruptionem et a corruptione in priuationem. Sed cum actui potentiae conueniant generatio et processio naturalius quam proprietates aliae, idcirco conueniens est quamplurimum actuum dignitatum eius [Dei] esse per modum generationis et processionis."

86 LAM, Prologue: "[...] et euntes intrauerunt quandam siluam amoenissimam arboribus, foliis, fructibus, fontibus, pratis et ripariis delectabilibus ineffabiliter redundantem. In illa autem silua inter se amicabiliter conferentes unus contra alterum."

87 See Yates, The Art of Ramon Lull, 153-154; Lola Badia, Teoria i pràctica de la literatura en Ramon Llull (Barcelona: Quaderns Crema, 1992), 83-85. 
Ordo and pulchritudo. From its very outset, LAM stresses the need for order and beauty within the dialogue if one wishes to attain the truth..$^{88}$ Some years later, in 1301, the Rhetorica noua once more champions the usefulness of these rhetorical elements if one wishes to achieve any agreement. ${ }^{89}$

Self-referential discourse and rationes necessariae. This work by Ramon Llull seeks to provide in and by itself all the elements necessary to support its philosophical arguments..$^{90}$ This is a typical feature of both Llull's philosophical and his theological works.

In order to bring this section to a proper conclusion, however, it is essential to call to mind the radical change in Llull's Christology. LAM serves as testimony to the evolution thereof from a mainstream theological doctrine to a conception close to that of the Franciscans, who rejected the notion that the Incarnation was a consequence of original sin, ${ }^{91}$ and, it should also be noted, as time went on, from a more retrospective, soteriologically focused view thereof to one that is more prospective and eschatological. ${ }^{92}$

88 LAM, Prologue: "Cumque sapientes haec omnia certo ordine studuissent, fuit facta inter eos dissensio"; "Quo audito iudaeus pulchro ordine suas rationes primitus inchoauit [...]." $L A M, 1.2$ : "Cum autem praedictae rationes pulchris argumentationibus explete finissent, iudaeus duxit ad terminum [...]." LAM, 1.1.2: "Nos autem probauimus et certo ordine significauimus Deum non esse incarnatum [...]." LAM, Epilogue: "Auditis hiis rationibus ab utroque sapientium et pulchro ordine terminatis, ambo longanimiter cogitarunt $[\ldots]$." "Quocirca proposuerunt se perseuerare diu in disputationibus secundum modum et ordinem supradictum, ut eorum intellectus in hiis praemissis rationibus fierent assidui iudicantes."

89 " [...] Cum uerbum sit medium et instrumentum per quod loquentes et audentes in unum finem conueniunt, consequitur ut quanto uerba fuerint amplius ordinata magisque ornata, tanto ampliori pulchritudine uenustentur; quantoque uerba fuerint pulchriora, tanto etiam audientibus placibiliora reddantur; quanto uero sunt placibiliora, tanto necesse est ut per ipsa loquentes et audientes in finem concorditer uniantur." Ramon Llull, Rhetorica noua, "Raimundi Lulli Opera Latina" xxx, ed. Jaume Medina (Turnhout: Brepols, 2005), Prologue, 22, 4-10. See Badia, Teoria i pràctica ..., 79-85. Johnston, "Introduction," in idem, Ramon Llull's New Rethoric. Text and Translation of Llull's Rethorica Noua (Davis CA: Hermagoras, 1994), xxi-xxiii.

90 "The fact that the Art worked with a strictly limited set of concepts also meant that it was, to coin a word, endo-referential: all the material it needed to construct its arguments was found within its own domains, with no need of any exterior input." Bonner, The Art and Logic, 291.

91 See note 44 .

92 Robert D. Hughes, personal communication 02/01/2015. 


\subsection{Manuscript Transmission and Editions}

For this edition, we have worked chiefly with the sole complete manuscript, namely, the codex of Reims, Bibliothèque de la Ville, $500(R)$. Nevertheless, when possible and necessary we have incorporated into the critical text readings from the manuscript of Milan, Biblioteca Ambrosiana, P 79 Sup. (M), which provides the beginning of the work alone. In addition, we also have taken into account, and included in the apparatus, the existing partial editions: by Carmelo Ottaviano (o), who edited part of the prologue from the Milan Ms; by Éphrem Longpré $(l)$, who edited some fragments (the beginning and the end of the work, and the opening parts of both the Jew's and the Christian's books) from the Reims Ms; and, finally, the edition by Walter Andreas Euler $(e)$ of some doctrinally interesting fragments, likewise from the Reims Ms. ${ }^{93}$

The description of the manuscripts which include the work is as follows: ${ }^{94}$

a) Reims, Bibliothèque de la Ville, 500. Early-fourteenth century $(R)^{95}$ Content

Fols. $1^{\mathrm{r}}-13^{\mathrm{r}}$ : RAMON LLULL, Liber de quattuordecim articulis catholicae fidei Romanae Ecclesiae sacrosanctae

Fols. $133^{\mathrm{r}}-149^{\mathrm{r}}$ : RAMON LLULL, Liber de aduentu Messiae

On parchment. Size: 255x180 mm. Contains 149 folios with two flyleaves which belong to a medical treatise. On folio $1^{\mathrm{r}}$ is written: "Liber Raymundi Lulli 160 (or 180)." The text is arranged in two columns, with 38 lines. The Liber de quattuordecim shows many corrections. The cover, badly-preserved, contains on its inside the arms of the canonry of Reims cathedral, and bears an old identification number: "Lit D. ord. 3, n. 44." Here there is also an inscription: "Raymundi

93 Carmelo Ottaviano, "Ricerche lulliane," Estudis Universitaris Catalans 14 (1929): 1-13; Éphrem, Longpré, “Le Ms. 500 de Reims et le «De adventu Messiae» de R. Lulle,” Estudis Franciscans 47 (1935): 66-68; Euler, “«De adventu Messiae»: Ramón Lulls Beitrag ...," 429441. There is also the edition by María del Carmen Fonollet Paños, Estudio, comentario y traducción del prólogo del De aduentu Messiae de Ramón Llull ..., 37-50, which we did not use for our edition on account of its provisional nature.

94 The descriptions of the manuscripts are provided from their referred catalogues and bibliography.

95 Catalogue: Henri Loriquet, Catalogue général des mss. des bibliothèques publiques de France. Départements; Reims (Paris: Librairie Plon, 1904), XxxviıI, 671-672. Cf. also Éphrem Longpré, "Le Ms. 500 de Reims et le «De aduentu Messiae» de R. Lulle ...," 6668 , where the incipits and explicit of each work are provided; and Euler, "«De aduentu Messiae»: Ramón Lulls Beitrag ...," 429-441. The chronology is provided by the catalogue. 
Lulli opus theologicum." On folio $149^{\mathrm{v}}$ there is a note by Giles of Aspromonte, the bishop's secretary and librarian. ${ }^{96}$

\section{b) Milan, Biblioteca Ambrosiana, $\mathrm{P} 79$ Sup. Sixteenth century $(M)^{97}$ Content}

Fols. $1^{\mathrm{r}}-67^{\mathrm{r}}$ : RAM ON LLULL, Declaratio Raimundiper modum dialogiedita contra aliquorum philosophorum et eorum sequacium opiniones

Fols. $73^{\mathrm{r}}-85^{\mathrm{r}}$ : RAMON LLULL, Liber de lumine

Fols. 86 $6^{\mathrm{r}}-86^{\mathrm{v}}$ : RAMON LLuLL, Liber de aduentu Messiae [extract]

Fols. $93^{\mathrm{r}}-115^{\mathrm{r}}$ : RAMON LLULL, Liber de ente reali et rationis

Fols. $116^{\mathrm{r}}-13^{\mathrm{v}}$ : RAMON LLULL, Liber de angelis

On paper. Size: $225 \times 180 \mathrm{~mm}$. Contains 138 folios and is written in a single column. On folio $67^{\mathrm{r}}$ a datation and the place where the copy was done are provided: "et hic ultimo transcriptus fuit Barcinoni anno 1567 mense julii." On folio $138^{\mathrm{v}}$ we read: "Libre Dios a Arzeo d'esta pena y guste de la gloria con Aldana." The manuscript only provides the opening text of $L A M$.

Due to the fact that $R$ (the older testimony) is the only manuscript containing the full work, the edition is almost completely based on it. Nevertheless, there are some copy mistakes. Therefore, in cases where grammar or semantic were impossible corrections have been inserted. The shortness of the testimony of $M$ prevents coming to a conclusion about the relation of both manuscripts. Former editions by Longpré, Ottaviano and Euler have not been followed, due to the fact that all of them are partial and based on only one manuscript.

96 According to Henry Loriquet, the note says: "Iste liber est de libris bonae memoriae domini Guidonis de Roya, quondam archiepiscopi Remensis, in quo sunt 149 folia, et sunt ibidem duo libri, uidelicet primus qui est maior, secundus quidem tractatus de collatione duorum virorum sapientium [...] quorum unus christianus erat et alter iudaeus, et multum se inuicem diligebant, quare ad salutem mundi huius laborabant. Si quis hunc librum furatus fuerit, anathema sit. Quotatus est per Egidium de Asperomonte, XIIII ${ }^{\text {a }}$ die maii, anno Domini MccCCXII ${ }^{\circ}$. Orate pro ipsis. Nota quod $2^{\text {us }}$ libellus contentus dicitur liber de Aduentu Messiae, primus qui maior est, uocatur liber de XIIII ${ }^{\mathrm{im}}$ Articulis fidei, et credo quod sit de doctrina illius Luli." Loriquet, Catalogue général des mss. des bibliothèques publiques de France ..., 672.

97 Catalogue: http://ambrosiana.comperio.it/opac/detail/view/ambro:catalog:85701 (from the project pertaining to the Catalogo Unico of the Biblioteca Ambrosiana). Cf. also Carmelo Ottaviano, L'«Ars compendiosa» de R. Lulle ..., n. 2o; idem, "Ricerche lulliane," Estudis Universitaris Catalans 14 (1929): 1-13. Further bibliography: Euler, "«De aduentu Messiae»: Ramón Lulls Beitrag ...", 430. This manuscript is likewise refered to in volumes XVI, XVII, Xx (pages xix, xxiv and lv, respectively) of the "Raimundi Lulli Opera Latina." 


\subsection{Remarks Concerning the Language in which LAM was Composed}

There are only few things we can say regarding the language of composition of Ramon Llull's works, which in many cases present a dual-language transmission. The text is in Latin, and until now no version in Catalan or in any other language has been identified, in contrast to the situation that obtains in the case of the Llibre del gentil (Catalan and Latin) and other works. Moreover, the various titles of the work in the catalogues are always in Latin. ${ }^{98}$ Despite this, and despite fact that $L A M$ belongs to an extensive tradition of texts in Latin, it is reasonable to conceive of the possibility of a primary version's having existed in the vernacular - as was the case, for example, with Llull's contemporary Alfonso of Valladolid's Mostrador de justicia in its Castilian form-for the reason that Jews and Christians shared Catalan as their lingua franca within the Crown of Aragon.

This edition has been established according to the guidelines of the "Raimundi Lulli Opera Latina" (ROL) series as applicable to critical editions. 'E-caudata' is written 'ae'. And:

$\begin{array}{lllll}\text { u } & \text { for } & \text { u } & \text { and } & \text { v } \\ V & \text { for } & \text { U } & \text { and } & \text { V } \\ \text { i } & \text { for } & \text { i } & \text { and } & \text { j } \\ \text { I } & \text { for } & \text { I } & \text { and } & \text { J }\end{array}$

The edition presents a reconstruction of classical orthography. In order to punctuate, the text we have followed the criterion of ease of contemporary reading, and, as regards sentences containing relative clauses, we have taken into consideration either their essential or their accidental role. The apparatus

98 In its Ramon Llull Database (Llull Dв), the Centre de Documentació Ramon Llull provides a list of the historical catalogues and inventories wherein the work appears: http://orbita.bib.ub.edu/llull/bo.asp?bo=II.A.18. For the the language in which Ramon Llull's works were composed, cf. Friedrich Stegmüller, "Lullus latinus. Zur kritischen Gesamtedition der lateinischen Werke des Raimundus Lullus," Estudios Lulianos 1 (1957): 91-95; Cf. Salvador Bové, "Ramon Llull i la llengua llatina," Boletín de la Real Academia de Buenas Letras de Barcelona 8 (1915): 65-88; Alexander Fidora, "Noch einmal Arbor scientiae oder Arbre de sciencia. Zum Verhältnis von lateinischer und katalanischer Fassung der llullschen Enzyklopädie," Faventia 25 (2003): 67-73; Elena Pistolesi, "Tradizione e traduzione nel corpus lulliano," Studia Lulliana 49 (2009): 3-50. 
is based on the negative principle. Thus, manuscripts and editions are not quoted unless their reading diverges from the text.

Sigla:

$R=$ Reims, Bibliothèque de la Ville, 500 .

$M=$ Milano, Biblioteca Ambrosiana, $\mathrm{P} 79$ Sup.

$l=$ Partial edition by Éphrem Longpré (Éphrem Longpré, "Le Ms. 500 de Reims et le «De adventu Messiae ...").

$o=$ Partial edition by Carmelo Ottaviano (Carmelo Ottaviano, "Ricerche ...").

$e=$ Partial edition by Walter Andreas Euler (Walter Andreas Euler, " De adventu Messiae»: Ramón Lulls Beitrag ...").

\section{Signa:}

[ ] Insertion by the editor of text not included in the manuscript

$\dagger$ Textual lacuna owing to the impossibility of reconstruction

Abbreviations:

$\begin{array}{ll}\text { add. } & \text { addidit } \\ \text { cod. } & \text { codex } \\ \text { corr. } & \text { correxit } \\ \text { del. } & \text { deleuit } \\ \text { iter. } & \text { iterauit } \\ \text { lin. } & \text { linea } \\ \text { marg. } & \text { margo } \\ \text { om. } & \text { omisit } \\ \text { tit. } & \text { titulus }\end{array}$

\section{LIBER DE ADVENTV MESSIAE}

(Critical Edition)

Deus, qui sanctus sanctorum es ${ }^{99}$ et gloriosus excellentissime in cunctisque dignitatibus infinitus, ${ }^{100}$ quidam homo pauper et ${ }^{101}$ peccator honorem tibi

\footnotetext{
99 es om. Mo.

100 infinitus add. es $M o$.

101 et om. Mo.
} 
impendere desiderat et seruire, compilando hoc praesens opus in quo de aduentu Messiae pertractatur. ${ }^{102}$

\section{De PROLOGo}

Duo uiri mirae sapientiae, quorum unus iudaeus, alter christianus erat, inhabitabant in quadam nobili ciuitate, alter alterum in bonis terrenis excellenter amore feruido diligens, ${ }^{103}$ qui proposuere altiore amore ${ }^{104}$ sese diligere ${ }^{105}$ in bonorum amoenitatibus diuinorum, ${ }^{106}$ quocirca quisque eorum desiderabat affectu nimio se $\mathrm{e}^{107}$ ambos in una fide consistere, in una lege, in una semita ueritatis, ut eorum amores adhuc ${ }^{108}$ possent in gradu altissimo duplicari. Quibus amoribus inter eos tam desideratis ipsi ab illa ciuitate progredientes et euntes intrauerunt quandam siluam amoenissimam arboribus, ${ }^{109}$ foliis, ${ }^{110}$ fructibus, fontibus, pratis et ripariis delectabilibus ineffabiliter redundantem. ${ }^{111}$

In illa autem silua inter se ${ }^{112}$ amicabiliter conferentes unus contra alterum, secundum scripta ${ }^{113}$ aduentus Messiae per longa tempora disputarunt, affirmante ipso christiano, $\left[R 133^{\mathrm{rb}}\right]$ dicente ipsum Messiam uenisse, quil ${ }^{114}$ Deus est et homo natus ex uirgine incorrupta. Iudaeus uero negans hoc et ${ }^{115}$ affirmans oppositum dicebat eum uenturum esse solum ${ }^{116}$ hominem et non Deum.

Maxime $^{117}$ disputatio et controuersia uertebantur ${ }^{118}$ inter hos duos sapientes $^{119}$ in prophetarum expositione, nam eorum quilibet conuertebat

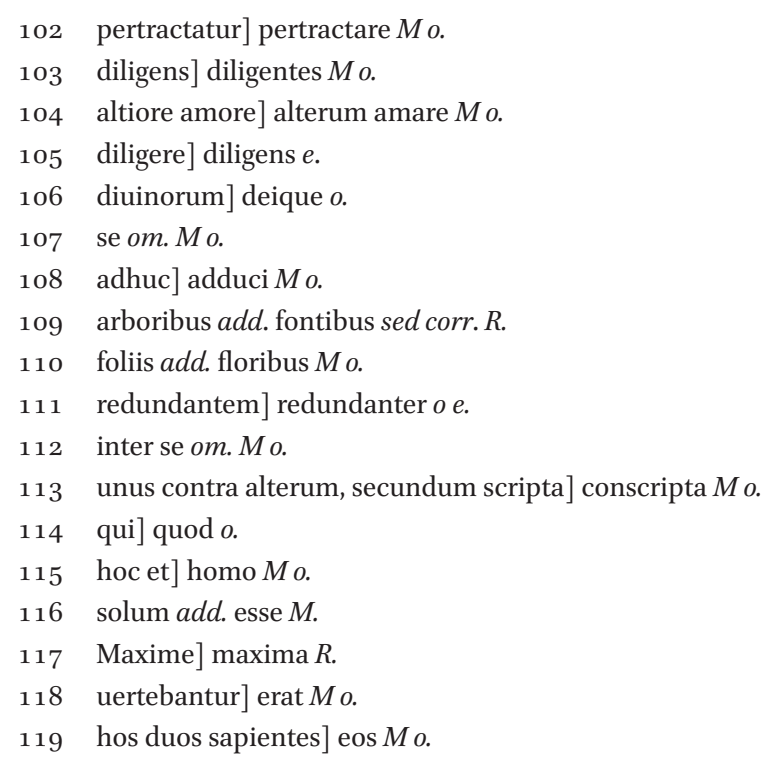


suae intentioni per glossas ${ }^{120}$ textum legis ueteris et prophetarum. Sed quia in simul ${ }^{121}$ conuenire non poterant et iam taedio afligi inceperant ${ }^{122}$ ipsi ambo per nimia ${ }^{123}$ obstantia in qua erant, idicirco fuerunt conturbati longanimiter ambo dulciter lacrimantes, uno eorum dicente flebiliter hos sermones:124

"Heu me, quantus error per uniuersum orbem uertitur, licet non habeamus nisi unum solum Deum, unum creatorem, ${ }^{125}$ unum super omnia dominantem. Et nos quidem omnes homines alii contra alios diuisi ${ }^{126}$ sumus, credendo in illum, et in illo et per illum inter nos inimici et contrarii facti sumus; qua siquidem ${ }^{127}$ inimicitia et contrarietate sunt guerrae, proelia, mortes, ${ }^{128}$ seruitutes, et multa inde malorum genera sortiuntur, quae nequaquam essent si nos uniuersi in una fide, una credulitate tantum unanimiter sisteremus, cognoscendo et diligendo Deum, qui creauit nos ut eum cognoscamus finaliter et amemus, et ut nos alter alterum diligamus et alter alteri seruiamus."

Dum autem $\left[R 133^{\text {va }}\right]$ iste sapiens hos sermones protulisset, ${ }^{129}$ lacrimando dixit illi:

"Cum per auctoritates ueritatem aduentus Messiae cognoscere nequeamus, saltem temptare bonum est, si eius aduentum ${ }^{130}$ cognoscere poterimus ${ }^{131}$ per necessarias ${ }^{132}$ rationes, nam ratio necessaria est aptior magisque ${ }^{133}$ intellectui apprehensiua $^{134}$ quam glossae seu expositio auctoritatum, et ideo bonum est $\mathrm{ut}^{135}$ disputemus per rationes necessarias ${ }^{136}$ et inquiremus ${ }^{137}\left[A 86^{\mathrm{v}}\right]$ Messiae aduentum diligenter, prout ordo dictauerit rationum.

\footnotetext{
120 eorum quilibet conuertebat suae intentioni per glossas] quilibet suae intentione conuertebat glossas et $M o$.

121 in simul om. Mo.

122 et iam ... inceperant in marg. R; et taedio afficiebantur $M o$.

123 per nimia] pernimia $e$.

124 ipsi ambo ... sermones] dulciter lacrimantes, unus eorum sic exsorsus est $M$.

125 creatorem add. et $M o$.

126 diuisi] diuersi $M o$.

127 siquidem] quidem $M o$.

128 mortes add. et $M o$.

129 protulisset add. alter emittens cordis suspiria $\mathrm{Mo}$.

130 aduentum add. temptare $M$.

131 poterimus] possimus $\mathrm{Mo}$.

132 necessarias] necessitas $R$.

133 magisque om. $\mathrm{Mo}$.

134 apprehensiua om. $\mathrm{Mo.}$

135 ut] quod $M o$.

136 rationes necessarias] necessarias rationes $M o$.

137 inquiremus] quaeramus $M o$; inquiramus $e$.
} 
Cumque sapiens hoc dixisset, tunc ambo unanimes concordarunt se disputare per demonstrationes et rationes ostensiuas, qui tunc et hunc praesentem librum ambo pariter ordinarunt, quem diuiserunt in duos libros partiales, quorum primus rationes iudaei sapientis continet, secundus uero rationes comprehendit quas edidit sapiens christianus.

Placuit autem eis ambobus in quolibet horum librorum tres conditiones ponere, per quas et cum quibus ipsi librorum ordinationes pariter sequerentur, quae siquidem conditiones in hiis consequentibus assignantur:

1. Prima enim conditio est de diuinis dignitatibus, quae sunt bonitas, magnitudo, aeternitas, potestas, sapientia, amor, perfectio, gloria, uirtus, ueritas, iustitia, largitas, misericordia, humilitas, domini $\left[R 133^{\mathrm{vb}}\right] \mathrm{um}$ et patientia, atque caeterae in istis omnibus uersantur. Hae autem dignitates in hoc libro considerantur tali modo, uidelicet ut illae rationes quae super aduentum Messiae uehementius significant et ostendunt actum nobiliorem $\dagger \dagger$ dignitatum iudicentur existere $\dagger \dagger$ ueritatis, et rationes illis oppositae iudicentur esse in semita falsitatis maxime, cum actus diuinarum dignitatum cum maioritate conueniant, quae sicut minoritate contra maioritatem conuenirent. Esset igitur actus dignitatis cuiuslibet maior per minoritatem et defectum quam per maioritatem et perfectionem, sed hoc est inconueniens manifeste.

2. Secunda uero conditio est de ${ }^{138}$ diuinis dignitatibus et septem uirtutibus, quibus mediantibus tenditur ad gloriam et obstatur uitiis et peccatis, quae quidem uirtutes sunt hae, uidelicet fides, spes, caritas, iustitia, prudentia, fortitudo, temperantia.

Hae autem conditiones statuuntur in inquisitione aduentus Messiae isto modo, uidelicet ut rationes quae in aduentu Messiae ostendunt manifeste maiorem concordantiam esse inter Dei dignitates et septem uirtutes praehibitas sint amabiles et affirmabiles; rationes uero illis contrariae sint negabiles penitus et odio habeantur maxime, cum maior dignitatum et uirtutum concordantia sit amabilior quam minor, et maior contrarietas negabilior sit quam minor.

3. Tertia autem $\left[R_{13} 4^{\text {ra }}\right]$ conditio est de septem uirtutibus antedictis, uidelicet ut rationes quae in aduentu Messiae maiorem denotabunt ${ }^{139}$ concordantiam inter unum actum uirtutis et alterum sint affirmabiles et amentur; sed rationes hiis oppositae, quae uirtutibus minorem denotabunt concordantiam seu quae in uirtutibus contrarietatem aliquam

138 de om. $R$.

139 denotabunt correxi ex denegabunt $R$. 
denotabunt, sint odibiles et negentur. Si enim haec ordinatio inconueniens existeret et contraria ueritati, sequeretur possibile esse uirtutes et uitia posse in suis actibus concordari, et quod uirtus et uirtus, et uitium et uitium actus obtinerent contrarios ${ }^{140}$ et discordes, et sic inconueniens non modicum sequeretur. Quo siquidem manifestum est praedictam conditionem esse decentem inquisitioni faciendae ad perscrutandum aduentus Messiae finaliter ueritatem.

Cumque sapientes haec omnia certo ordine studuissent, fuit facta inter eos dissensio, ${ }^{141}$ quis eorum primus inciperet suas proponere rationes, nam propter dilectionem affectabat in inceptione alter alterum uenerari. Iudaeo $\dagger \dagger$ sua $\dagger$ ipsi christiano ut primus inciperet dignaretur, cui christianus respondit dicens se nolle primo incipere, nam insinuabat rationis ordo quod iudaeus primo inciperet ratiocinari, eo quod lex uetus iudaica multo prius traxit exordium quam noua lex christiana.

Quo audito iudaeus pulchro ordi $\left[R_{134}{ }^{\mathrm{rb}}\right]$ ne suas rationes primitus inchoauit.

\section{INCIPIT LIBER PRIMVS}

Iudaeus primo incipiens diuisit suum librum in duas distinctiones, quarum prima est de negatione, secunda de affirmatione. Harum autem distinctionum primam diuisit in tres partes, in quarum prima negat ipse Messiam uenisse, negando in Deo esse Trinitatem, negandoque Incarnationem Filii Dei Domini Iesu Christi; negando etiam mundum non adhuc suscepisse perfectionem, quae sibi conuenit secundum ea, quae olim prophetae in suis carminibus cecinere. In hac siquidem prima parte intendit iudaeus per has tres negationes probare Messiam non uenisse, et quamlibet negationem per tres conditiones praehibitas nititur demonstrare.

Secunda uero distinctio est affirmationis quam facit iudaeus, dum probare intendit Messiam esse futurum propter praehibitam perfectionem necessariam toti mundo, ut eius aduentus mundo perfectionem quae sibi conuenit largiatur, prout apparet per dicta antiquissima prophetarum. Itaque hanc distinctionem probare proponit per tres conditiones, per quas discurrit ordinatio $^{142}$ huius libri.

\footnotetext{
140 contrarios correxi ex contrario $R$.

141 dissensio corr. ex dissensione $R$.

142 ordinatio] ordinationem $e$.
} 
[1.1.1] Incipit prima distinctio et prima pars

Trinitatem in Deo esse negat iudaeus manifeste, quae quidem negatio est per primam conditionem, pro $\left[R 134^{\text {va }}\right]$ ferens hos ${ }^{143}$ sermones:

"Si in Deo existeret Trinitas, esset quidem ${ }^{144}$ pluralitas esse in eo, qua ${ }^{145}$ siquidem pluralitate ${ }^{146}$ esset in eo compositio unitatis, quae quidem compositio foret simplicitati contraria, quae etiam simplicitas conuenit et concordat cum diuinis dignitatibus et actualitatibus earum; sed quoniam compositio et minoritas ${ }^{147}$ cum priuatione conueniant et defectu, ob hoc impossibile est in Deo pluralitatem esse, quo quidem impossibilitati est impossibile in Deo Trinitatem existere, quae Trinitas absque pluralitate in Deo nequit esse.

$\mathrm{Si}$ in Deo paternitas, filiatio et processio, esset igitur in Deo compositio maioritatis et minoritatis in dignitatibus diuinis, quia Pater esset in bonitate, magnitudine et caetera primor et maior Filio, maxime cum omnem Patrem deceat Filio prius esse et in dignitatibus maiorem, atque bonitas Patris et Filii esset prior et maior quod bonitas Sancti Spiritus, quae procederet ab utroque.

Sed quoniam inconueniens est maioritatem et minoritatem esse in Dei essentia, ergo impossibile est generationem et processionem in Deo esse intrinsece ullo modo. Diuinae dignitates sunt in diuina perfectione ita maxime quod unus Deus sufficit in se habere omnes dignitates quas dii infiniti habere possent, quare superfluitas esset plurimos deos esse, postquam unus sufficit omni $\left[R 134^{\mathrm{vb}}\right]$ bus hiis quae possent habere dii infiniti.

Vnde, cum hoc ita sit, ergo ostensum est manifeste Dei unitatem sufficientem esse toti perfectioni dignitatum absque pluralitate, quae quidem pluralitas esset ita superflua in Dei unitate sicut esset superflua existentibus diis multis. Si enim Deus Pater generaret Deum Filium et Sanctus Spiritus ab utroque procederet, essent ergo tres dii in proprietatibus, in dignitatibus et in essentia distincti, et sic Dei unitas destrueretur, cuius destructione diuinae dignitates carerent hiis in quibus ipsae essent tantummodo unus Deus, et destruerent penitus earum ${ }^{148}$ conditiones." ${ }^{149}$

\section{De secunda conditione}

Memoratus est inde secundae conditionis, per quam Messiam uenisse denegat, proferens ista uerba:

\footnotetext{
143 hos] has $e$.

144 quidem] quod $e$.

145 quia] $e$.

146 pluralitate] pluralitatem $e$.

147 minoritas] numeritas $e$.

148 earum add. et $R$.

149 conditiones] operationes $e$.
} 
"Fides est lumen mentis illuminatae lumine gratiae super posse ${ }^{150}$ intellectus, et spes potestas animae confidentis in diuina gratia, misericordia, iustitia et potestate; atque caritas est uirtus communis coniungens animam ad suscipiendum gratiam a Deo. Vnde si Deus in Trinitatem existeret, esset igitur defectiuus, prout supra dictum est, quo siquidem defectu hae tres dictae uirtutes non haberent tantam aptitudinem et opportunitatem ad suscipiendum gratam benedictionem et influentiam a dignitatibus diuinis. Sed quoniam $\left[R 135^{\mathrm{ra}}\right]$ maior opportunitas et influentia quam uirtutes habere possint et suscipere a diuinarum gratia dignitatum cum esse conueniat, ergo manifestum est in Deo nullatenus existere Trinitatem.

Iustitia est reddere unicuique quod suum est, et prudentia est scire bonum et malum ad operandum bonum, ad malum euitandum; et fortitudo est nobilitas animae ${ }^{151}$ quae super uitia triumphans in medio ${ }^{152}$ superfluitatis et paucitatis compellit existere uirtutem, atque temperantia est medium existens contrarium et diuersum duobus terminis, concordantibus aequalibus uitiis et peccatis. Vnde si uerum esset in Deo Trinitatem existere, foret igitur contrarietas non modica inter diuinas dignitates et animae uirtutes, qua siquidem contrarietate diuinae dignitates sibi ipsis contrariarentur, nec humanae uirtutes existerent diuinis dignitatibus aduersantes, nam trium deorum quisque per se solum absque relinquis niteret tres uirtutes animae possidere, nec uirtutes se possent habere melius ad unum deum quam ad alterum, postquam a quolibet creationem et influentiam aequaliter acceptarent."

\section{De tertia conditione}

"Tertia conditio est ut omnes praedictae uirtutes concordantiam habeant, aliae cum aliis et quaelibet cum actu suo operando bonum et destruendo septem delicta mortalia, quae uidelicet sunt hae: gula, luxuria, aua $\left[R 135^{\mathrm{rb}}\right]$ ritia, superbia, accidia, inuidia et ira. Vnde, si Deus in Trinitate existeret et quaelibet persona Deus esset, sequeretur, dum fides in Deo Patre crederet sumere actu suo unum Deum pro obiecto, quod actus quod habet accipiendo diuinum Filium et diuinum Spiritum Sanctum pro obiecto esset in priuatione, in potentia aut in habitu. Quod si sic esset, sequeretur quod fides nominata perfecta esset in suo actu ${ }^{153}$ accipiendo unum Deum pro obiecto, sicut ut duos alios similiter et semel ${ }^{154}$ pro obiecto non acciperet, sicut si sit unus Deus tantum,

\footnotetext{
$15^{\circ}$ posse correxi ex potens $R$.

$15^{1}$ animae] animi $R$.

152 medio add. extremitatum in marg. $R$.

153 actu] auctu $R$.

154 semel in marg. $R$.
} 
in quo pluralitas nulla consistat. Et hoc idem quod de fide sequitur, sequeretur ${ }^{155}$ de spe, caritate et caetera.

Itaque existeret aduersitas inter unam uirtutem et alteram, eo quod si fides Patrem pro obiecto acciperet, spes uero in alio tempore acciperet Filium pro obiecto, et caritas Spiritum Sanctum, nec sic earum actualitates conuenirent in eodem tempore ad cognoscendum, diligendum et honorandum unum Deum, tantum ei oboediendum.

Hoc autem est inconueniens manifeste ostendens uirtutes alias cum aliis et uitia alia cum aliis aduersari; etiam alia uitia essent concordantia cum aliis uirtutibus, et alia uitia cum aliis uitiis secundum diuersa tempora, diuersos actus et obiecta."

Per has tres conditiones et per rationes praehibitas intellixit probare iudaeus Messiam non adhuc uenisse, qui si uenisset, ipse esset Christus quem christiani affir $\left[R 135^{\mathrm{va}}\right]$ mant unum Deum esse. Sed cum Messias de necessitate uenturus sit, et in Deo non possit esse pluralitas nec Trinitas, prout iam probauimus, et pluralitas et Trinitas in Deo essent si ille esset Messias quem christiani dicunt uenisse, quae Trinitas et pluralitas non possunt esse, prout iam probauimus, ergo manifeste ostenditur Messiam non uenisse.

[1.1.2] Incipit pars secunda

\section{Et conditio prima}

"Manifestum est diuinas dignitates infinitas esse et habere actus suos infinitos. Si autem Deus foret incarnatus, natura diuina terminata existeret et finita in Incarnatione quam assumpsit, maxime cum illa Incarnatio terminata sit et finita. Et sic ${ }^{156}$ per illam Incarnationem sequeretur diuinam naturam se alterari ex infinitate in finitatem et terminationem, quod est impossibile, quia si esset possibile, forent igitur actus diuinae uoluntatis et potestatis contrarii actibus iustitiae et perfectionis eius. Quia nisi sic essent contrarii, certe finitas, alteratio, minoritas et defectus essent aequales Dei magnitudini, aeternitati et perfectioni. Hoc autem est inconueniens, quo quidem probatur impossibile esse, secundum supradicta inconuenientia, quod Deus fuerit incarnatus."

Postquam iudaeus has rationes terminasset, iterum sumpsit alias rationes dicens:

"Si Deus naturam hominis assumpsisset, foret igitur natura diuina in partes diuisa, eo quod huma $\left[R 135^{\mathrm{vb}}\right]$ na natura in quantum terminata est et finita non sufficit ad essendum per totam naturam diuinam, existentem infinitam in bonitate, magnitudine, aeternitate, potestate et caetera.

155 sequeretur in marg. $R$.

156 sic] caetera $e$. 
Sed quoniam inconueniens est et impossibile naturam diuinam esse diuisibilem, et impossibile etiam quod res finita alterare possit et diuidere rem infinitam, ergo impossibile est quod Deus sibi ipsi coniunxit et uniuit naturam creatam finitam, quia inde sequerentur inconuenientia supradicta; atque actus diuinarum dignitatum mutationem haberent in habitu et potentia, atque conuenientia haberent cum priuatione et defectu.

Manifestum est diuinam dignitatem nullam in se habere operis superfluitatem nec defectum alicuius rei, nam si intrinsece haberent [sic] opus superfluum aut defectiuum, essent igitur Dei uoluntas, potestas et iustitia contra ipsius bonitatem, magnitudinem, sapientiam et perfectionem. Hoc autem est inconueniens quo significatur manifeste et ostenditur quod si Deus foret incarnatus, illa ergo Incarnatio aut esset superflua aut necessaria dignitatibus diuinis; hoc autem est inconueniens: dignitas in se ipsa foret actui suo contraria. Hoc autem est inconueniens maxime, cum inter diuinas dignitates et suos actus nulla differentia possit esse."

\section{De secunda conditione}

"Si Deus naturam creatam sibi ipsi coniunxisset sic ut natura incarnata unirentur ut existerent una persona, esset ergo illa persona ex maioritate, perfectione et aeternitate et ex minori[ $\left.R_{13} 6^{\text {ra }}\right]$ tate, priuatione et defectu composita; quod si sic esset, sequeretur igitur contrarietatem existere inter diuinas dignitates et uirtutes humanas, quoniam, sicut in corpore composito ex quattuor elementis ipsa elementa contrariantur aliis alia, ita in illa persona esset magnitudo contra paruitatem, et perfectio contra defectum et aeternitas contra principium in fide, spe, caritate, iustitia et caetera, atque e conuerso. Si igitur talis contrarietas esset in illa persona, foret ergo in ea corruptio et naturae diuinae diuisio et ${ }^{157}$ humanae.

Si Christus Deus et homo existeret, esset ergo contrarietas inter diuinam iustitiam et humanam dum humana anima recolendo, intelligendo et diligendo sumeret aequaliter pro obiecto ipsum Iesum Christum, ipso existente solum una persona. $\mathrm{Nam}^{158}$ oportet diuinam iustitiam tali modo iustificare in dignitatibus diuinis in tribus potentiis animae, ut homo sit recolens, intelligens et diligens diuinam naturam uehementius quam humanam naturam. Sed quoniam humana iustitia nequit in uno tempore obiectum diuinae naturae et humanae attribuere actibus memoriae, intellectus et uoluntatis, esset in Deo ipsa contra

157 et in marg. $R$.

158 nam corr. ex una in marg. $R$. 
iustitiam diuinam, si aequaliter pro obiecto actibus trium potentiarum ${ }^{159}$ attribueret naturam diuinam et humanam.

Si autem uerum esset Christum esse Deum et hominem, iustitia igitur in Deo et iustitia in homine inter se contrariarentur, eo quod diuina iustitia cum iniuria conueniret, in quantum iustum corpus Christi, cum quo unita foret, uilescere permitteret, crucifigendo, occidendo $\left[R_{13} 6^{\mathrm{rb}}\right]$. Atque iustitia ipsius hominis Deo oboediens et unita cum diuina iustitia conueniret cum iustitia per oboedientiam, aut cum iniuria per impatientiam, quod si sic esset, sequeretur compositio et concordantia actus iustitiae et iniuriae ${ }^{160}$ in actibus iustitiae et iniuriae. Hoc autem est inconueniens maxime, cum iustitia et iniuria contrarientur."

\section{De tertia ${ }^{161}$ conditione}

"Tantum est ${ }^{162}$ inconueniens et contra cursum naturae Christum esse Deum et hominem quod sic ${ }^{163}$ fides et prudentia inter se bene adhaerere nequunt nec conuenire, quia fides credens Deum hominem esse est magis distans ab intelligere quam fides credens Deum nequaquam hominem esse posse. Si autem uerum esset Christum esse Deum et hominem, sequeretur quod humanus intellectus plus posset contra actum cursus ${ }^{164}$ naturalis quam secundum actum naturae, atque iustitia humana nequiret in caritate, spe et fortitudine ita uehementer coniungere fidem et prudentiam sicut si Deus homo nequeat esse unum. Cum hoc ita sit, si igitur Christus sit Deus et homo, per illam ergo coniunctionem possunt esse uirtutes magis distantes una ab altera, atque uirtutes et uitia inde possunt esse in suis actibus propinquiores et in proprietatibus similiores. Cum enim maior uirtutum distantia sit odibilis, ergo de necessitate conuenit ut maior uirtutum et uitiorum propinquitas odibilis existat $\left[R_{13} 6^{\mathrm{va}}\right]$.

Quia siquidem odibilitate est odibile Deum incarnatum esse, caritas et iustitia accidiae et inuidiae aduersantur; si autem Christus sit Deus et homo, est ergo Deus occasio in illo homine, quod caritas et iustitia cum accidia et inuidia concordes fiant, eo quod si Deus humanam naturam sumpserit in homine solo, est ergo ipse Deus occasio ut multi homines inuideant illi homini quem Deus

\footnotetext{
159 potentiarum add. animae in marg. $R$.

160 iniuriae correxi ex iustitiae $R$.

161 tertia] prima $R$.

162 est correxi ex cum $R$.

163 sic correxi ex si $R$.

164 cursus] cursu $R$.
} 
sibi unitum adunauit, et Deus esset accidiosus ex eo, ${ }^{165}$ quod se posset in pluribus hominibus incarnari nec se uoluit incarnari nisi unico homine tantum.

Humilitas et superbia, prudentia et ignorantia aduersantur. Si autem Christus sit Deus et homo, ipsius humanitas tantum exaltata est quod efficitur occasio ipsi superbiae. Et quoniam Deus aduentum huius hominis non explanat clarius in canticis prophetarum, est idcirco Deus cum ignorantia contra prudentiam concordans. Qua siquidem ignorantia nos iudaei pluresque populi non credimus sed potius speramus illum hominem propter ignorantiam ad quam Deus nos conuenire facit contra prudentiam in illo homine, si enim uerum sit illum hominem Deum esse. Sed quoniam inconueniens et impossibile est Deum esse occasionem contrarietatis inter uirtutem et uirtutem, et ipsum esse occasionem concordantiae uirtutum et uitiorum, ergo clariter manifestum est nullum hominem Deum esse.

Nos autem probaui[ $\left[R_{13} 6^{\mathrm{vb}}\right]$ mus et certo ordine significauimus Deum non esse incarnatum, quia, si incarnatus esset, sequerentur in tribus conditionibus inconuenientia supradicta, in quibus conditionibus sunt ipsa inconuenientia impossibilia, qua siquidem impossibilitate euidenter apparet adhuc Messiam non uenisse, quoniam si uenisset in esse diuino et humano, conditiones praedictae essent penitus distintae."

\section{[1.1.3] Incipit tertia pars}

\section{Et prima conditio}

Diuinas dignitates attribuit iudaeus pro obiecto actibus suae memoriae, intellectus et uoluntatis, ideoque subintulit hos sermones dicens:

"Secundum ea quae significant diuinae dignitates humano intellectui, oportet intellectum intelligere Deum benedictum ${ }^{166}$ creare hominem principaliter ut ab illo homine cognoscatur et ametur maxime, cum res nobilior quam intellectus et uoluntas hominis possint intelligere et diligere est ipse Deus benedictus, et idcirco oportet ut hoc in quo actus intellectus et uoluntatis nobiliores possint existere sit finaliter intentio, per quam omnis homo creatus est. Quod nisi sic esset, forent igitur diuinae dignitates contrariae diuini magnitudini et perfectioni, sed hoc est inconueniens manifeste."

Postquam autem iudaeus locutus fuit de principiis quibus homo creatus est, incepit loqui de medio per quod homo creatus est ad finalem intentionem, ad quam necesse est uenire secundum ordinationem principii et dignitatum praedictam. $\left[R 137^{\mathrm{ra}}\right]$ Quocirca dicit iudaeus medium existens inter principium et finem, per quam homo creatus est, esse tribulationes et labores qui per

165 eo in marg. $R$.

166 benedictum correxi ex benedicantur ipse $R$. 
mundum undique agitantur propter guerras, captiuitates, diuersitates, sectas, credulitates, prosperitates, diuitias, dominationes et caetera, quae per uniuersum saeculum decurrunt. Et sic pro hiis omnibus reperit homo sibi statum ut uirtutibus contra uitia possit uti, unde hoc medium ordinatum esse conuenit a dignitatibus diuinis; quae nisi sic essent, sequeretur ergo ordinationem principii et finis, quibus homo creatus est, non esse a diuinis dignitatibus ordinatam. Hoc praedictum medium existit materia, in quam ueniat forma causae finalis ad quam homo creatus est. Et quoniam principium et medium sunt in esse, prout supra probatum est, ergo necesse est finem esse, quae nisi esset foret principium et medium sine fine; hoc autem est inconueniens atque falsum maxime. Et cum diuinae dignitates maiorem habeant concordantiam cum intentione finali, ad quam homo creatus est, quam cum principio et medio, quibus homo creatus est, hoc enim est quia finalis intentio excedit principium et medium nobilitate.

Cumque iudaeus probasset principium, medium atque finem, quibus homo creatus est, negauit protinus dicens finem, uidelicet complementum quod per Messiam dari conuenit, non adhuc uenisse per ullum prophetam $\left[R 137^{\mathrm{rb}}\right]$, nec per ullum qui fuerit in tempore antiquo, quoniam finalem intentionem, qua Messias uenturus est, oportet esse in tanta perfectione, secundum Dei dignitates, quod nullum defectum patiatur; quae nisi perfectionem haberet, uero essent ergo defectus in dignitatibus diuinis, atque perfectio existeret in maiori quantitate in principio et medio quam in causa finali. Sed hoc est inconueniens quo clare manifestatur Messiam non uenisse, quoniam si uenisset aut haec $^{167}$ finalis intentio suo aduentu ad perfectionem uenisset, aut illa finalis intentio, ad quam ${ }^{168}$ homo creatus est, concordans existeret cum priuatione et defectu, quod est inconueniens manifeste.

\section{De secunda conditione}

Recoluit iudaeus fidem, spem, caritatem caeterasque uirtutes, atque recoluit diuinas dignitates considerans concordantiam quae decet actibus diuinarum dignitatum et dictarum uirtutum secundum statum in quo mundus fuit olim in antiquo tempore et secundum statum in quo nunc mundus uersatur, et protulit hos sermones dicens:

"Si sic foret, quod Messias uenisset, nos qui in captiuitatem redacti sumus a captiuitate liberi essemus, quia captiuitas qua detinemur est praeoccupatio nimia actibus nostrarum uirtutum, quare non ualeamus ita bene uti eis, tenendo legem creatam nobis, sicut si essemus a hac $\left[R 137^{\text {va }}\right]$ captiuitate liberati.

167 haec] hic $e$.

168 quam] quem $e$. 
Vnde, cum omnibus iudaeis sit nostra captiuitas generalis et contraria libero arbitrio quod conuenit ad utendum perfecte uirtutibus, ergo decet de necessitate, si Messias uenit, quod simus liberati a iugo captiuitatis.

Sed quia captiuitas adhuc nos detinet, ergo manifeste probatur Messiam non uenisse, quia si uenisset esset igitur contrarietas inter diuinas dignitates et uirtutes nostras, eo quod diuinae dignitates ordinassent minime in aduentu Messiae de liberatione nostra, quae conuenit nostrarum actibus uirtutum.

Manifestum est iudaeos esse in captiuitate christianorum et sarracenorum, et propter seruitutem in qua detenti sunt patiuntur labores plurimos et paupertates, et superati sunt a gentibus et coacti. Et quoniam nihilominus propter hos labores et languores deliquerunt ${ }^{169}$ sanctam legem suam datam Moysi, iustum est eos habere meritum pro laboribus quos passi sunt, quia nisi meritum haberent essent fortitudo, iustitia, caritas, fides et spes diuinis dignitatibus contrariantes. Si uero Messias aduenerit, nec eius aduentus iudaeis remunerauerit pro laboribus sustentatis, ergo eius aduentus diuinis dignitatibus et humanis uirtutibus contrariatur, conueniens cum peccatis; hoc enim est impossibile, quo aperte probatur $\left[R 137^{\mathrm{vb}}\right]$ adhuc Messiam non uenisse.

Prophetae de aduentu Messiae prophetauerunt per diuinas dignitates Messiam uenturum esse hominem genitum ex semine uiri et mulieris, et eum esse regem potentem, uirtuosum, sapientem et iustum ${ }^{170}$ filium, qui per nimiam potestatem suam faciet guerras et proelia in quibus malos homines deuincet et superabit. Iste uero propter uirtutem suam multa portendet munditia, et propter sapientiam suam ostendet ueritatem omnem destruens falsitatem. Etiam propter suam largitatem pleraque munera largietur atque suo populo conferet multa bona, secundum quod praedictum est a prophetis. Et propter haec omnia dominabitur uniuerso mundo, et exercet iustitiam per quam totus orbis conuertetur in pacem quam sancti prophetae olim prognosticauerunt.

Sed quoniam talis homo deceat esse Messias nec talis homo ullo tempore fuerit nec mundus fuerit nec est in statu qui finali causae conuenit in aduentu Messiae, ergo probatur euidentissime Messiam non uenisse, quia si uenisset esset quidem contrarietas inter diuinas dignitates et uirtutes nostras, quae in illis dignitatibus non ignorarent defectum ueritatis, iustitiae, sapientiae, perfectionis et uirtutis."

169 deliquerunt] delinquunt $e$.

170 iustum conieci ex Ieremias 23:5-6: "Ecce dies ueniunt ait Dominus et suscitabo David germen iustum et regnabit rex et sapiens erit et faciet iudicium et iustitiam in terra. In diebus illis saluabitur Iuda et Israhel habitabit confidenter et hoc est nomen quod uocabunt eum Dominus iustus noster." 


\section{De tertia conditione}

"Omnino contrariantur fides diffidentiae et spes desperantiae et caritas irae et iustitia iniuriae et prudentia ignorantiae et fortitudo fragilitati, atque [R13 $8^{\mathrm{ra}}$ ] temperantia impatientiae. Fides uero spes, caritas, iustitia, prudentia, fortitudo et temperantia maximam contra sua aduersaria habent concordantiam, quae quidem aduersantes ${ }^{171}$ etiam uirtutes maiorem habent concordantiam in maioritate quam in minoritate. Ideoque sunt magis contrariae peccatis et uitiis in maioritate quam in minoritate, atque ipsae uirtutes concordant cum esse et perfectione, et uitia et peccata cum priuatione et defectu.

Sed cum ab illa hora qua orbus plasmatus fuit usque nunc fuerit maior multitudo uitiorum quam uirtutum, ergo manifeste denotatur Messiam non uenisse, quoniam si uenisset certe eius aduentus multiplicasset tam uehementer uirtutes contra uitia et peccata quod in centuplo plures uirtutes quam uitia essent in mundo. Et nisi per aduentum eius essent multiplicatae uirtutes in tanta quantitate quod plures essent quam uitia, eius quidem aduentus esset superfluus nec ullam gessisset utilitatem, quod est inconueniens manifeste.

Si spes sperat et caritas diligit quod propter aduentum Messiae omnes homines qui in eius tempore fuerunt dirigantur in una fide, in una lege, sequitur inde maior actus iustitiae in actu spei et caritatis. Sed quoniam in antiquis temporibus non omnes homines in una lege, una fide crediderunt, nec adhuc credunt, $\left[R 138^{\mathrm{rb}}\right]$ sed potius in diuersis, ergo clare manifestum est Messiam non uenisse, quoniam si uenisset, fuisset ${ }^{172}$ enim tempus in quo homines uniuersi una fide, una lege credidissent Deum esse. Et nisi Deum unimode credidissent, sequeretur actus uirtutum non potuisse uenisse ad perfectionem, quae ipsis actibus conuenit, nec haberent uirtutes prout conuenit quibus possent uitiis aduersari.

Si uirtutes absque aduentu Messiae peruenissent ad perfectionem actuum sibi conuenientium, ipsae quidem non ita bene concordarent dictis prophetarum desiderantium affectu nimio ipsius Messiae aduentum. Sed quoniam maior conuenientia uirtutum eorum est affirmabilis, ergo est negabile Messiam iam uenisse. Quoniam si eum uenisse sit affirmabile, est ergo negabile magnam esse concordantiam uirtutum in sanctis prophetis contra uitia, quod autem est negabile, qua siquidem negatione est affirmabile Messiam esse uenturum."

171 aduersantes add. similiter habent concordantiam contra uirtutes in marg. $R$.

172 fuisset correxi ex finisset $R$. 


\section{[1.2] Incipit secunda distinctio}

\section{Et prima conditio}

Recoluit iudaeus quomodo partes negationis probauerunt Messiam non uenisse. Et quoniam Messiam esse conueniat secundum dicta prophetarum et prout de necessitate probatum est in parte tertia negationis, ergo de necessitate conuenit Messiam uenturum esse. Qui, nisi uenturus sit, contrarietas sequitur esse in diuinis $\left[R_{13} 8^{\text {va }}\right]$ dignitatibus, eo quod bonitas esset contraria ueritati, in quantum aduentum Messiae ordinasset in contradictione in hoc quod Messias uenisset et non uenisset; et sic eius aduentus esset praeteritus et futurus, itaque bonitas et ueritas essent contrariae in Dei iustitia et perfectione. Hoc autem est impossibile, quo quidem impossibili affirmandum est secundum concordantiam diuinarum dignitatum Messiam uenturum esse.

\section{De secunda conditione}

Cum in Deo non sit Trinitas nec sit incarnatus, secundum ea ${ }^{173}$ quae iam probauimus, nec fuerit tempus nec pax nec utilitas quae aduentui Messiae conueniunt, ergo decet Messiam non uenisse, sed potius uenturum esse. Vnde nos igitur affirmamus aduentum Messiae per tres negationes in concordantia quam diuinae dignitates habent in uirtutibus qui in homine existunt. Quoniam si Messias uenisset et fides crederet et spes speraret et caritas diligeret eius aduentum in ordinatione quam faciunt diuinae dignitates, etiam quod per eius aduentum oporteret Deum contra suas dignitates existere in Trinitate et incarnatum, nec compleret ea quae dicta sunt per os ${ }^{174}$ prophetarum. Foret ergo contrarietas inter Dei dignitates et uirtutes nostras, eo quia iustitia iustificare nequiret fidem, spem, caritatem in digni $\left[R_{13} 8^{\mathrm{vb}}\right]$ tatibus diuinis. Sed quoniam inconueniens est contradictio uirtutes, existentes uirtutes in suis actualitatibus, esse posse contrariantes dignitatibus diuinis, ergo affirmabile est Messiam non uenisse.

\section{De tertia conditione}

Recoluit iudaeus quomodo affirmatio quam facit de aduentu Messiae, quae uenturum esse perhibet, sumit exordium et deriuatur a tribus negationibus quas ipse apposuit propter inconuenientia, quae sequerentur si Messias aduenisset. Et ideo iudaeus proposuit dicens:

"Si Messias uenisset et esset inconueniens eum uenisse atque sit conueniens eum uenturum esse nec ullo tempore ueniat, est ergo conueniens

\footnotetext{
173 ea correxi ex inea $R$.

174 sunt per os corr. ex est per ho in marg. $R$.
} 
contrarietatem esse inter fidem, spem, caritatem, iustitiam et prudentiam, eo quia non haberent in quo conuenire possent in aduentu Messiae, in quantum actus cuiusque uirtutis conuenire posset cum ueritate aut cum falsitate contra actum alterius uirtutis, quoniam cum affirmatione et negatione, et cum ueritate, conuenirent in aduentu Messiae."

Cum autem praedictae rationes pulchris argumentationibus explete finissent, iudaeus duxit ad ${ }^{175}$ terminum sua uerba dicens et affirmans illa tres negationes in prima distinctione contentas esse antecedentes illius affirmationis, quae est consequens. Et quoniam in consequenti est perfectio propter perfectionem antecedentis, idcirco iudae $\left[R 139^{\text {ra }}\right]$ us ita compendiose elocutus est in distinctione secunda, et propter haec omnia hortatus est christianum ut suas rationes incipere dignaretur.

\section{INCIPIT SECVNDVS LIBER}

Christianus toto animo confidens in Dei auxilio, quod in necessitatis tempore nunquam fidelibus deficere consueuit, diuisit librum suum in duas distinctiones, quarum prima est de affirmatione, secunda uero de negatione. Praeterea primam duarum distinctionum uoluit diuidere in tres partes, quarum prima est probare in Deo Trinitatem existere personarum, secunda uero est probare Incarnationem Filii Dei Domini Ihesu Christi, sed tertia est probare mundum suam habuisse perfectionem in aduentu Messiae secundum perfectionem quae mundo conuenit in antiquo tempore elapso et etiam in tempore in quo sumus. Secunda autem distinctio est primae distinctionis conclusio negantis Messiam uenturum esse.

In hiis uero duabus distinctionibus uoluit christianus procedere per tales conditiones prout existit ordinatum, et quia de prioribus prior est speculatio, idcirco primo ad primum uersus fuit christianus probare Dei Trinitatem contra rationes et ${ }^{176}$ argumenta quibus iudaeus ipsam negauerat Trinitatem.

[2.1.1] De prima distinctione in prima parte

Si conueniens esset in Deo non esse pluralitatem ut compositio non sequatur in Deo, $\left[R 139^{\mathrm{rb}}\right]$ essent igitur Dei bonitas et potestas in minoritate uirtutis et simplicitatis, atque perfectio, bonitas et potestas essent contra magnitudinem ueritatis, iustitiae, gloriae, sapientiae et uoluntatis. Nam maior uirtus est Dei simplicitas in infinita bonitate, perfectione et gloria, si esse possit in unitate et in pluralitate absque compositione, quam si uetatet et abhorreret in

175 ad in marg. $R$.

176 et in marg. $R$. 
pluralitate existere, ut non existeret in compositione. Sed quoniam sapientia et uoluntas concordant in Deo cum iustitia, ergo oportet quod iustitia, potestas, sapientia et uoluntas existant in Deo actus maxime, cum in Deo sit maior simplicitas, perfectio quam possit esse, quae siquidem maior simplicitas esset in Deo priuatio, si propter timorem compositionis euitaret habere maiorem in se pluralitatem. Sed cum pluralitas quae in Deo existit sit sanctae Trinitatis demonstratio, atque pluralitas conueniat in Deo esse, prout idem probatum existit, ergo manifeste ${ }^{177}$ probatur Trinitas in Deo esse.

Si autem in Deo non sunt paternitas, filiatio et processio causa euitandi compositionem maioritatis, esset ergo uirtutis minoritas in Dei bonitate, magnitudine et aeternitate, cui siquidem minoritate esset contraria maioritas diuinae potestatis, sapientiae, uoluntatis et iustitiae; eo quia actus $\left[R 139^{\mathrm{va}}\right]$ potestatis, sapientiae, uoluntatis et iustitiae maiorem habent concordantiam cum maioritate aequalitatis, quae ${ }^{178}$ per paternitatem, filiationem et processionem non existat concordans nec composita cum minoritate, qua illi actus, qui per paternitatem, filiationem, processionem conueniunt, acquirent cum aequalitate Patris et Filii et Spiritus Sancti in bonitate, magnitudine, aeternitate et caetera. Sed cum iustitia concordantiam habeat cum gloria et perfectione, ergo de necessitate decet, ut ipsa iustificet in aequalitate maiori quae possit esse ex paternitate, filiatione et processione ${ }^{179}$ in dignitatibus diuinis.

Si foret superfluitas esse actus in diuinis dignitatibus ergo odiret iustitia in Dei uoluntate, ita actus dignitatum diuinarum sicut Dei uoluntas in sua iustitia odit quod perfectio, cui unus Deus sufficit, sit distincta in multis diis qui in multis essentiis diuersis permaneant et distincti. Ac si actus ipsarum dignitatum essent odibiles in distinctis proprietatibus pluribus, eo quod non sequatur essentiarum diuersitas quibus essentiis insequatur multos deos esse, unum distinctum ab altero, ergo propter iustitiam et sapientiam Dei uoluntas diligit in suis dignitatibus actuum priuationem, quorum quidem priuatione forent ipsae dignitates maiores et $\left[R_{139}{ }^{\mathrm{vb}}\right]$ uirtute et perfectione absque actibus quam cum actibus. Hoc autem est inconueniens significans et ostendens quod illa potestatis maioritas esse decet in actibus dignitatum, qua quidem maioritate sequi possint gloria et iustitia maiores, propter unitatem dignitatum et actuum earum in esse unius essentiae tantum et solius Dei.

Si propter generationem et processionem, quae in Deo sunt, sequeretur de necessitate essentiarum distinctio, quae quidem essentiae existerent dii distincti, quos impossibile esset esse unam essentiam, unum Deum tantum,

\footnotetext{
177 manifeste] magnifeste sic $R$.

178 quae correxi ex qui $R$.

179 processione correxi ex processiones $R$.
} 
sequeretur igitur quod infinitus actus simplicitatis diuinae existens per omnes Dei dignitates esset terminatus et finitus. Hoc autem est inconueniens, quo mediante christianus incepit hos sermones dicens:

"Si magnitudo infinita esset in quantitate in qua existeret corruptio absque generatione et processione infinitae magnitudinis et aeternae, foret siquidem possibile ut entitas infinitae magnitudinis, subiecta infinitae corruptioni concordare posset illam substantiam magnam et infinitam priuatione $\mathrm{e}^{180}$ et non esse. Sed quoniam diuina essentia existit infinita in uirtute et aeternitate, ergo decet actus dignitatum eius in se habere id per quod plus distent a priuatione, quia nisi illud haberent, sequeretur aliquam esse propinquitatem inter Deum et priuationem, quod est inconueniens, quo manifeste ostendetur et declaratur generationem et processio $\left[R 140^{\mathrm{ra}}\right]$ nem in Deo existere de necessitate."

Postquam christianus rationes soluisset quibus iudaeus intendebat Trinitatem denegare in Deo existere, tunc ipse christianus ad Trinitatem probandam subinferens hos sermones dixit:

"Certum et euidens est secundum cursum naturalem quod ignis simplex potestatem habet in igne composito, nam praeter illam potestatem ignis simplex generare nequiret ex prima materia ignem compositum in materia secunda. Vnde si ignis in suamet natura potestatem habet generandi alterum ignem, et iste actus sit ${ }^{181}$ ei prius et naturalior quam ipse actus quem ${ }^{182}$ ignis habet in aere et in caeteris elementis, de necessitate sequitur quod Deus in actu diuinarum dignitatum potestatem habeat in Deo et potestatem in potestate, et bonum in bono, et magnum in magno atque aeternum in aeterno, et hoc idem sequitur de caeteris dignitatibus diuinis; etiam quod actus Dei in Deo, et potestatis in potestate, et boni in bono sit simplex et infinitus absque compositione, qui nisi sic esset, sequeretur in elementis esse maiorem aptitudinem quam in dignitatibus diuinis. Hoc autem est inconueniens euidenter.

Error manifestus est affirmare in Deo esse minoritatem, ergo oportet ut actus intellectus, dum se ipsum intelligit, sit essentiae in infinita magnitudine bonitatis, aeternitatis et caetera, cum magnitudine suae infinitae essentiae in bonitate, aeternitate et caetera. Vnde cum haec ita sint, ergo oportet, dum actus sui intellectus se ipsum intelligit bonum, aeternum, $\left[R 140^{\mathrm{rb}}\right]$ infinitum et caetera, ut ipse generaret aequalem sibi ipsi in entitate infinitae bonitatis, magnitudinis et caetera, qui quidem Deus et deitas existat, nam praeter talem generationem esset impossibile actum intellectus posse aequalem esse toti Dei entitati, sicut est impossibile actum uoluntatis humanae posse aequalem

\footnotetext{
180 priuatione correxi ex priuationi $R$.

181 sit corr. ex si in marg. $R$.

182 quem correxi ex quae $R$.
} 
esse toti humanitati et toti hominis entitati, cui siquidem aequalis existeret si $^{183}$ homo intelligendo hominem, hominem generaret. ${ }^{184}$

Secundum perfectam actualitatem diuinarum dignitatum inconueniens est negare Deum diligere semet ipsum, quoniam nisi se ipsum diligeret aut semet odiret, esset quidem actus uoluntatis eius contrarius actui suae iustitiae et perfectionis. Ergo manifestum est Deum non odire, sed potius diligere se ipsum. Sed si se ipsum diligat, oportet ut bonificet, magnificet et aeternificet in se ipso, et hoc idem sequitur de omnibus dignitatibus, quod nisi sic esset, sequeretur quod actus suae uoluntatis foret principalior quam actus suae bonitatis et magnitudinis et caetera. Hoc autem est inconueniens manifeste.

Si autem Deus in essentia et dignitatibus communibus bonificaret et magnificaret se absque distinctione distinctarum personarum, faceret igitur Deus se ipsum et sic essent idem absque ulla distinctione bonificans et bonificatus, magnificans et magnificatus, et caetera. Sed hoc est $\left[R 140^{\mathrm{va}}\right]$ contradictio qua mediante sequeretur quod uoluntas perfectionem odiret in suo actu ${ }^{185}$ et in actibus omnium Dei ${ }^{186}$ dignitatum, et diligeret confusionem esse in actibus supradictis.

Nisi uero in Dei entitate fuisset opus intrinsecum priusquam uniuersus orbis crearetur, Deus quidem conueniret cum minoritate actuum in suis dignitatibus priusquam mundus esset, conuenissetque cum maioritate tunc temporis quandoque mundus creatus fuerit ab actibus diuinarum dignitatum operantibus in eodem. Atque actus infinitatis non haberet tantam concordantiam in infinitis actibus, uidelicet in posse, uelle et scire, sicut in finitis. Etiam ${ }^{187}$ esset ita inconueniens quod infinitum haberet actum ${ }^{188}$ in infinitum sicut finitum in infinitum, ${ }^{189}$ atque Dei actus aeternus maiorem haberet aptitudinem in operando aeternaliter per actum aeternalem extra suam entitatem et nunquam

183 si in marg. $R$.

184 Cf. the reasoning from the Llibre contra Anticrist, composed during the same years: "E açó es inconvenient per lo qual es significat que la volentat e l'enteniment de Deu son Deu e que lur obre es Deu, egual a Deu (...). E enaxí com en home entendre no es egual en quantitat a home, hans es home major que son entendre, enaxí en Deu sa obra no seria egual a si mateix si entenent e amant si matex no engenrrava agual a si matex en entendre e amar e bonificar, magnificar, etc." Ramon Llull, Llibre contra Anticrist, "Nova Edició de les Obres de Ramon Llull” III, ed. Antoni Joan Pons i Pons, Jordi Gayà Estelrich, Gret Schib Torra (Palma de Mallorca: Patronat Ramon Llull, 1996) ii, 226-338.

185 actu correxi ex auctu $R$ e.

186 Dei] diuinorum $e$.

187 Etiam] et $e$.

188 actum correxi ex actuum $R$.

189 finitum in infinitum correxi ex in finitum in infinitum $R$; in finitum. In infinitum $e$. 
intra. Et sic esset mundus aeternus, nec fuisset primus homo nec futurus esset nouissimus, nec Dei sapientia scire posset finitum numerum in indiuiduis humanae speciei, eo quod nullus numerus infinite et aeterne multiplicatus comprehendi possit a sapientia, nec existere in quantitate. Sed quia inconueniens est Dei sapientiam in hoc finitam existere, ergo conueniens $\left[R 140^{\mathrm{vb}}\right]$ mundum non esse aeternum nec sine principio esse posse."

Vnde per haec omnia inconuenientia et conuenientia supradicta significauit et ostendit christianus iudaeo in Deo existere Trinitatem.

Quaestio. Hiis rationibus propositis et ostensis, iudaeus retinere non potuit quin quaestionem faceret christiano dicens:

"Si quattuor personae aut plures essent in Deo, maioritas conueniret cum diuina bonitate uehementius quam si sint tantum in eo tres personae?"

Solutio. Quibus christianus respondens dixit:

"Vna paternitas, una filiatio, una processio in actibus diuinarum dignitatum $^{190}$ ita perfectione sufficiunt sicut una dignitatum diuinae sufficit entitati. Hoc autem est propter infinitatem quae est in tribus personis diuinis ex actibus infinitis in Dei dignitatibus infinitis, quoniam si in Deo essent duae aut plures paternitates, filiationes, processiones, essent quidem omnes finitae in suis dignitatibus. Sed hoc est inconueniens manifeste."

Quaestio. Interim quaesiuit iudaeus:

"Quare potius in Deo conueniunt paternitas, filiatio, processio quam caeterae proprietates?"

Respondit ei christianus dicens:

"Ignis et caetera elementa non habent potestatem habendi actum in se ipsis nec unum in alterum absque generatione et processione et caetera; ea per quae maxime species existunt in conseruatione sunt generatio et processio, quibus earum indiuidua perueniunt in esse, atque propter ${ }^{191}$ priuationem $\left[R 141^{\mathrm{ra}}\right]$ generationis et processionis perueniunt in corruptionem et a corruptione in priuationem.

Sed cum actui potentiae conueniant generatio et processio naturalius quam proprietates aliae, idcirco conueniens est quamplurimum actuum ${ }^{192}$ dignitatum eius esse per modum generationis et processionis, quia nisi sic esset, forent igitur in creatura actus conuenientiores cum potentia et entitate essentiae quam in Deo dignitates ${ }^{193}$ eius, in entitate essentiae et deitatis, et hoc est inconueniens euidenter."

\footnotetext{
190 dignitatum $a d d$. per $R$.

191 propter in marg. $R$.

192 actuum correxi ex actus $R$.

193 dignitates correxi ex dignitatum $R$.
} 


\section{De conditione secunda}

"Si in Deo sit personarum Trinitas generante infinite Deo Patre Deum Filium cum infinito actu infinitae bonitatis, magnitudinis, aeternitatis et caetera, et ab utroque, uidelicet ex Patre et Filio procedat Spiritus Sanctus, habente qualibet persona actus infinitos in omnibus diuinis dignitatibus, et in simul sint ipsae tres personae una essentia, una entitas diuina habens actum infinitum in cunctis dignitatibus suis; atque fides credat in Deo hanc talem Trinitatem existere, et spes speret gratam uirtutem, iustitiam et misericordiam ab hac Trinitate, et etiam caritas diligat hanc Trinitatem in unitate, et unitatem in Trinitate; sequitur idcirco in uirtutibus maioritas actuum et maior concordantia esse inter dignitates Dei et uirtutes. Nec est propterea Trinitas in Deo minor, sed cum haec quibus diuinae $\left[R \mathbf{R}^{\mathrm{rb}}{ }^{\mathrm{rb}}\right]$ dignitates et uirtutes creatae maiorem habent concordantiam, in quibus sint magis distantes a contrarietate et a priuatione actuum, conueniat esse de necessitate secundum diuinas conditiones, ergo manifeste declarant in Deo existere Trinitatem.

Iustificare est actus iustitiae et prudentificare actus prudentiae et fortificare actus fortitudinis, etiam temperare est temperantiae actus; unde si multi dii essent, diuersi in entitate et essentia, et eorum quisque uellet in praedictis actibus dominari, atque ipsi actus fuissent cuilibet deorum dediti et obligati, foret sic accidia, inuidia et iniuria in deorum quolibet, eo quod ipsi actus non in uno tempore neque sub una dominatione seruire possent ipsis diis. Et sic inciderent in culpam absque libero arbitrio, atque essent isti actus diuinis dignitatibus aduersantes.

Sed si in Deo sit personarum Trinitas et qualibet earum Deus sit, et sint in simul tantummodo Deus unus, et quilibet istorum actuum seruiendo uni personae seruiat aliis duabus, et seruiendo soli Deo seruiat ipsis tribus personis et omnibus dignitatibus diuinis, sequitur in Deo maior concordantia esse inter diuinas dignitates et uirtutes, ${ }^{194}$ quae siquidem maior concordantia aperte ostenditur in maioritate actuum uirtutum. Nam in quantum earum actualitas maior est, in tanto maior esse potuit $\left[R 141^{\text {va }}\right]$ concordantia quam cum diuinis dignitatibus habent. Vnde nisi in Deo esset Trinitas, esset quidem uirtus quaelibet apta et conueniens ad habendum maiorem actum propter propriam naturam sui quam propter influentiam diuinarum dignitatum. Hoc autem est inconueniens euidentissime, quo manifeste ostenditur in Deo existere Trinitatem."

\section{De tertia conditione}

"In diuina essentia idem sunt Deus et deitas, ens et entitas, bonitas et bonificare, magnitudo et magnificare et caetera; ideoque dum fides, spes, caritas

194 et uirtutes in marg. $R$. 
habeant pro obiecto Deum aut deitatem et caetera, habent tunc pro obiecto aequaliter ea quae praedicta sunt. Si autem in Deo sit personarum Trinitas, et una persona distincta sit ab altera ita quod una non sit altera et quaelibet personarum sit Deus et deitas, ens et entitas, bonitas et bonificare et caetera, etiam quod fides, spes et caritas habentes unam personarum pro obiecto habeant pro obiecto omnia quae de Deo praedicta sunt, sequitur inde maior concordantia esse inter unam uirtutem et alteram, et propter hanc maiorem concordantiam suscipiunt ipsae maiorem influentiam ab dignitatibus ad essendum magnae aduersantes uitiis et peccatis.

Sed si in Deo sit Trinitas personarum, et una uirtus habens pro obiecto unam personam non habeat pro obiecto alteram nec essentiam nec Dei dignitates, sic uirtutes in actu sunt maiores in se ipsis $\left[R 141^{\mathrm{vb}}\right]$ quam in Deo, etiam cum una uirtus habens suum actum contra aliquod uitium participet de necessitate cum actu alterius uirtutis. Vnde, quia hoc ita est, sequitur, si in Deo non esset Trinitas, quod anima in suis uirtutibus maiorem haberet concordantiam propter distinctionem et concordantiam quam in Deo propter unitatem absque distinctione. Hoc autem est inconueniens, quo mediante Dei Trinitas designatur."

Per tres conditiones praehibitas probauit efficaciter christianus in Deo existere Trinitatem, qua mediante probauit Messiam iam ${ }^{195}$ uenisse; qua siquidem per obiectum opposuit christianus propter conditionem secundum quam iudaeus per negationem intellexit probare Messiam uenturum esse.

[2.1.2] Incipit secunda pars

\section{Prima conditio}

"Sicut Deo placuit ordinare obiecta sensualia corporalis sensibus, in quibus ipsi possint habere actus et sensualia opera, eo modo sibi placuit ordinare obiecta intellectualia animae potentiis ut ipsae potentiae actus et opera spiritualia ualeant excedere. Quocirca Deus uoluit ordinare ut natura diuina efficeretur homo et homo uniretur Deo ut excederet cum ipso Deo unita persona, eo quod intellectus humanus illam Incarnationem habeat pro obiecto, qua quidem Incarnatione ${ }^{196}$ accipiat pro obiecto magnos actus diuinarum dignitatum, nam maiores actus bonitatis, magnitudinis, aeternitatis, potestatis, sapientiae et caetera significat $\left[R 142^{\text {ra }}\right]$ esse in diuinis dignitatibus si Deus fuerit incarnatus, ipso tamen non existente alterato nec terminato in natura nec in proprietatibus, quam si non fuerit incarnatus. Sed cum haec conueniant cum dignitatibus diuinis, quibus magnitudo actuum earum se melius attribuit et

195 iam in marg. $R$.

196 Incarnatione corr. in marg. $R$. 
manifestat pro obiecto humanae memoriae, intellectui et uoluntati, ergo oportet Deum esse incarnatum, qui nisi incarnatus esset ipse quidem contrariaretur maioritati secundum quam humana discretio et ratio habere possunt melius obiectum ex actibus dignitatum eius. Hoc autem est inconueniens manifeste.

Deum esse hominem et hominem esse Deum sit ut tota deitas quam sibi ${ }^{197}$ uniuit homo sit homo, et totus ille homo coniunctus sit deitati, nec ob hoc ipsa deitas diuisa sit ab infinitate, nec homo ille infinitus sit, neque eiectus a natura hominis.

Est maior actus bonitatis, potentiae, magnitudinis, uoluntatis et sapientiae quam humanus intellectus possit intelligere et scire in actibus quos diuinae dignitates habent in creatura; sed si diuina uoluntas illam maiorem actualitatem non diligeret, contrariaretur iustitiae in magnitudine actuum dignitatum ac etiam in maiori influentia quam humanus intellectus suscipire ualeat ex actibus quos diuinae dignitates habent in creatura.

Si uero Deus non habeat uoluntatem essendi incarnatus ut $\left[R 142^{\text {rb }}\right]$ potestatem non habeat, est ergo actus potestatis contrarius actui sapientiae scientis in potestate infinitos actus perfectionis et uirtutis. Sed hoc est inconueniens aperte, unde, ad ostendendum hoc inconueniens, uoluit Deus incarnari.

Absque eius Incarnatione non posset tam manifeste fieri demonstratio ex magnitudine actuum diuinarum dignitatum, nec esset ille homo qui posset suscipere obiectum quod dignitatibus diuinis conuenit, qui siquidem homo est dominus Ihesus Christus.

Actus cuiusque dignitatis diuinae est ita perfectus in bonitate, magnitudine et caetera, quod impossibile est eum quicquam facere superfluum aut necessarium sibi ipsi, nam minoritas et defectus conuenirent cum actibus diuinae magnitudinis et perfectionis. Vnde, ad manifestandum melius humano intellectui Deum non aliquod superfluum nec necessarium facere in se ipso, uoluit ipse incarnari ut per eius Incarnationem reuelatum sit melius homini necessitatem et superfluitatem esse impossibiles diuinarum actibus dignitatum, quoniam si diuina uoluntas Incarnationem odiret ne in ea secundum actum Trinitatis superfluitas aut necessitas ostendatur, actus enim uoluntatis non ita ${ }^{198}$ bene conueniret cum actu magnitudinis in actu potestatis, perfectionis et sapientiae sicut si Deus sit incarnatus. Qua siquidem Incarnatione humanus intellectus melius potest intelligere magnam $\left[R 142^{\text {va }}\right]$ necessitatem quam creatura habet ad suscipiendum Dei uirtutem, perfectionem, bonitatem et largitatem, cuius necessitatis magnitudine existente maxima demonstratur melius actus

197 sibi in marg. $R$.

198 non ita corr. ex nominata in marg. $R$. 
diuinarum dignitatum aduersari actibus superfluitatis, et conuenire uehementius cum utilitate ${ }^{199}$ creaturae per Incarnationem quam absque Incarnatione.

Postquam autem christianus rationes soluisset quas iudaeus opposuerat Incarnationi domini Dei nostri, quam, scilicet Incarnationem, probauit ipse christianus ad destructionem rationum quas ipse iudaeus exposuit, tunc uoluit probare interim ipsam Incarnationem, secundum haec, sermones dicens:

"Manifestum est Deum posse habere maiores actus dignitatum in se quam extra se, maxime cum omnia quae in Deo sunt infinita sint, et omnia quae extra Deum sunt terminata sint et finita. Sed si Deus humanam naturam sumpsit, potest illam maiorem facere intra naturam suam quam extra; et ut illud opus sit in maiori concordantia cum actu magnitudinis in uirtute, gloria et perfectione per actum iustitiae concordantis cum maioritate actuum uirtutis, perfectionis et gloriae, dum uoluit Deus incarnari in natura hominis, ut ipse homo cognosceret et amaret actus diuinos in maxima magnitudine, quae conuenit dignitatibus Dei.

In quanto autem actus gloriae maior est in creato, distantior est et magis contrarius actu $\left[R 142^{\mathrm{vb}}\right]$ i poenae, qui siquidem actus poenae destructus esset penitus in creatura, si inter actus gloriae et iustitiae contrarietas esset, in quibus est aeternalis concordantia et infinita. Qua siquidem concordantia significatur Incarnatio manifeste, quoniam si Deus incarnatus sit, actus diuinae gloriae maiorem gloriam homini impendit atque actus diuinae iustitiae est inde maior in attribuendo maiorem poenam homini peccatori, qui credens Dei Incarnationem maiorem culpam meretur si peccet quam si peccaret ignorans Dei Incarnationem. Vnde Deus uoluit homo esse ut actus gloriae et iustitiae maiores usus exerceant in creaturis. Si uero Dei uoluntas odiret Deum esse hominem, actus uoluntatis esset odiens maioritatem in actibus gloriae et iustitiae, quod est inconueniens manifeste."

\section{De secunda conditione}

"Si in homine corpus esset homo et etiam anima esset homo, et corpus et anima distincta essent in hominis entitate et in simul existerent unus homo, sequeretur maior concordantia inter actus sensuum sensualium et actus sensuum intellectualium.

Vnde, cum hoc ita sit, ergo in suppositione praedictae metaphorae soluit christianus rationem quam iudaeus opposuerat Incarnationi. Quoniam si Deus sit homo et homo sit Deus absque contrarietate diuinarum dignitatum et humanarum uirtutum, ergo potest inde esse maioritas actuum inter diuinas dignitates et humanas uir $\left[R_{14} 3^{\text {ra }}\right]$ tutes, et quoniam maior concordantia esse

199 utilitate corr. ex uilitate in marg. $R$. 
potest in esse Dei hominis et hominis Dei, ergo designatur in maiori concordantia Deum uoluisse hominem esse. Si autem Deus odiret se esse hominem ut non concordaret cum hominis entitate, in qua ipse existeret homo, ergo esset minoritas potestatis, perfectionis et uirtutis contra magnitudinem bonitatis, gloriae et largitatis. Hoc autem est inconueniens et contra maioritatem actuum congruentium fidei, spei, caritati et caetera.

Si diuina potestas possificet humanum intellectum in tanta magnitudine, dum Christum intelligit Deum et hominem esse, quod intelligendo humanitatem in Ihesu Christo pro obiecto habeat Dei naturam et entitatem, et si diuina uoluntas uolificat tam excellenter et tam feruenter uoluntatem hominis, dum ipsa Deum et hominem diligit in Ihesu Christo, quod diligendo habeat pro obiecto Dei entitatem et naturam, atque ambo, uidelicet intellectus et uoluntas, intelligendo et diligendo ${ }^{200}$ Dei entitatem et naturam habeant pro obiecto naturam et entitatem hominis in Ihesu Christo, sequitur maior actualitas concordantiae inter diuinas dignitates et humanas uirtutes.

Si autem Deus non uult ${ }^{201}$ nec uoluit esse homo, sequitur maioritatem bonitatis, perfectionis, potestatis et sapientiae aduersari iustitiae diuinae, cui siquidem maioritati esset contraria maioritas humanae iustitiae in fide, spe, caritate, prudentia ${ }^{202}$ et fortitudine. Hoc autem est in $\left[R 143^{\mathrm{rb}}\right]$ conueniens, quo manifestissime demonstratur Dei iustitiam iustificare ita uehementer iustitiam hominis simul et semel recolentis, intelligentis et amantis Deum et hominem in Ihesu Christo, quod homo ille propter iustitiam iustificatam recolit, intelligit et diligit simul et aequaliter Deum et hominem, atque meminit, intelligit et diligit ${ }^{203}$ simul et semel Deum fortius quam hominem et tamen propter hoc sequitur contradictio nulla. Sed si ob hoc contradictio incideret, sequeretur esse actum minoritatis in diuinis dignitatibus contra actum maioritatis in maiori unione Dei et hominis, et actum uirtutum atque obiecti ${ }^{204}$ obiectati actibus diuinarum dignitatum et humanarum uirtutum. Hoc autem est inconueniens euidenter.

Si homo intelligit et diligit uitium, actus eius est uitium, sed si intelligat et diligat iustitiam, actus suae intelligentiae est uirtus, quae nisi sic essent, sequeretur igitur quod actus uoluntatis non haberet maius meritum aut maiorem culpam per intelligentiam quam per ignorantiam. Sed hoc est inconueniens, quo metaphorice soluitur argumentum quod iudaeus ediderat contra Dei

\footnotetext{
200 et diligendo in marg. $R$.

201 uult corr. ex uoluit in marg. $R$.

202 in fide ... prudentia in marg. $R$.

203 diligit add. et diligit $R$.

204 obiecti in marg. $R$.
} 
Incarnationem; quoniam si Deus sit homo et homo sit finitus, terminatus et mortalis, nec tamen Deus sit alteratus nec corruptus nec motus a sua entitate propter Incarnationem, ergo denotatur impossibilitas $\left[R 143^{\text {va }}\right]$ quod finitas, mors, terminatio mutare possint defectum in Deo, nec esse occasio illius defectus in Deo. Atque humana iustitia inde concordat melius in hominis intellectu et uoluntate, in quanto magis oboediens est Deo, quoniam ad demonstrandum actus suarum dignitatum uoluit ut illa humanitas quam assumpsit apponeret supplicio et morti, propter humani generis liberationem."

\section{De tertia conditione}

"Manifestum est actum fidei esse posse maiorem in uirtute in quanto uehementius credit homo super cursum naturae et intellectus intelligit, atque habet maiorem actum intelligendo per actus diuinarum dignitatum quam per actus naturae. Quocirca sequitur fidem et prudentiam esse posse maiores ac habere maiores actus si Deus sit homo et homo Deus. Nisi uero hoc ${ }^{205}$ ita esset, sequeretur quod fides et prudentia habere possent maiores operis actualitates propter minora obiecta, in quibus minus est operis et uirtutis, quam propter maiora. Hoc autem est inconueniens manifeste ostendens quod in quanto uehementius fides et prudentia diuersa sunt in suis officiis in tanto propter maiores actus esse possunt uehementius concordantes; quae nisi hanc haberent possibilitatem, esset igitur impossibile maiorem diuersitatem concordare posse melius $\left[R 143^{\mathrm{vb}}\right]$ in actibus uirtutum quam minorem, atque diuersitas maior maiorem haberet concordantiam cum contrarietate quam cum concordantia. Itaque sequeretur quod in quanto fortius uirtutes confusae forent in suis actualitatibus in tanto uirtuosae magis essent quam in distinctione actuum earum. Hoc autem est inconueniens atque falsum.

In quanto caritas et iustitia sunt in maioritate uirtutis in tanto possunt contra inuidiam et accidiam melius conuenire. Si enim Deus sit unus homo tantum et unus homo tantum sit Deus, caritas et iustitia esse possunt in maiori quantitate quam si Deum esse liceret ${ }^{206}$ plures homines incarnatos. Significaretur etiam quod melius esset uirtus in nihilo quam in magnitudine sui ipsius, ${ }^{207}$ et sui actus etiam esset maior in multis diis quam in Deo solo, sed hoc est inconueniens quo soluit breuiter iudaei argumentum et aperte demonstratur unum Deum decere esse unum hominem tantum.

Si autem homo sit Deus et ille homo, propter exaltationem quam accipit in uirtute et nobilitate in essendo Deum, occasionaretur esse superbum, et sic

\footnotetext{
205 hoc $a d d$. hoc $R$.

206 liceret in marg. $R$.

207 ipsius add. et sui ipsius $R$.
} 
designaretur superbiam habere concondantiam cum Dei humilitate, quod est inconueniens atque falsum. Quo significatur Deum esse hominem ut illum hominem ${ }^{208} \mathrm{hu}\left[R_{\left.144^{\text {ra }}\right]}\right]$ miliaret paupertati ad demonstrandum Dei humilitatem esse seu fuisse in illo homine quamplurimum superbiae et aduersantem. ${ }^{209}$

Ratio autem quare Deus non ${ }^{210}$ explanauit clarius aduentum domini Ihesu Christi per prophetas secundum litteralem explanationem fuit haec, ${ }^{211}$ uidelicet ut humanus intellectus occasionem haberet se exaltandi in expositione morali et spirituali, et ut homines se inclinare possent melius ad actum fidei concordantis cum actu uoluntatis et cum actu necessariarum rationum, in exaltato actu intellectus. Vnde cum hoc ita sit, ergo clare manifestus est uoluntatem et intellectum conuenire posse melius cum maioritate in quantum non ${ }^{212}$ manifeste denuntiatus fuit aduentus Ihesu Christi."

Secundum tres praehibitas conditiones soluta sunt argumenta quae fecerat iudaeus contra Incarnationem Fillii Dei, atque reuelatur et ostenditur manifeste secundum illas conditiones Messiam uenisse in propria natura diuina et humana. ${ }^{213}$ Qui, nisi cum natura diuina et humana uenisset, essent conditiones magis uirtuosae in minoritate uirtuosorum actuum quam in maioritate. Hoc autem est inconueniens, quo Ihesus Christus suum benedictum aduentum reuelat humano intellectui perscrutanti eum secundum praehibitas conditiones.

[2.1.3] Incipit tertia pars

\section{Et prima conditio}

Christianus concessit princi $\left[R 144^{\mathrm{rb}}\right]$ pium, medium et finem esse per finalem intentionem existentem ut Deus cognoscatur et ametur, et probare per diuinas dignitates conatus fuit Messiam iam uenisse dicens has rationes:

208 hominem add. ut ullum hominem ut ullum hominem $R$.

209 Cf. similar reasoning from the Llibre contra Anticrist: "E volent esser sens fi lo Fill Deu home Deu, lo qual home Deu humilia la humilitat de Deu ha pobretat, turments, mort en aquest mon, en la cual mort del home Deu fo humiliat [1]o Deu home en sa humanitat matexa; en la qual humanitat e pobresa, turments e mort lo poder e la justicia de Deu pogren pus luny lunyar a superbia l'actu de humilitat per encarnació e per mort que sens encarnació e sens mort, pero lo qual major lunyament poch esser major en granesa la concordança de humilitat e son actu." Ramon Llull, Llibre contra Anticrist ..., 13, 619-626.

210 non in marg. $R$.

211 haec] hoc $e$.

212 non addidi ex sensu.

213 et humana add. in marg. $R$. 
"Manifestum est quod secundum nobilitatem principii et finis necesse est ${ }^{214}$ medium, ut per illud medium principium et finis ualeant conuenire sic ut medii nobilitas procedat a principio et a fine, uirtute per illlud mouente se a principio usque ad finem. Vnde, cum aduentus Messiae sit medium per quod sit finis, ergo si Messias uenerit, uirtus propinquiorum est quae se mouet ad finem. Sin autem uenerit, distantior est a fine, cum autem maior propinquitas perfectionis in causa finali sit, cum actu diuinae uoluntatis in Dei bonitate, iustitia et misericordia magis concordans quam minor. Ergo aperte designatur si Messias iam uenerit nos esse propinquiores causae finali quam essemus si uenturus esset.

Si uero maior distantia perfectionis causae finalis concordaret cum actibus diuinae iustitiae, bonitatis et misericordiae, ergo uoluntas, iustitia et bonitas existerent contrariae Dei aeternitati, magnitudini, sapientiae et perfectioni. Hoc autem est inconueniens et impossibile, quo manifeste apparet Messiam iam uenisse.

Finalis quidem intentio ${ }^{215}$ in $\left[R 144^{\mathrm{va}}\right]$ qua iudaei aduentum Messiae desiderant est secundum hanc beatitudinem terrenam, et secundum deliberationem corporum a captiuitate. Christiani uero finalem intentionem habent olim uenisse Messiam ad deliberationem humani generis a captiuitate intellectuali et a peccato originali, praestando spiritualem gloriam, et ad conferendum inter Deum et hominem maiorem concordantiam et pacem.

Et ideo maioritas et bonitas maiorem habent concordantiam in aduentu Messiae, in quanto eius aduentus maiorem habet concordantiam cum maiori causa finali quam cum minori. Qua siquidem maioritate probatur euidentissime Messiam aduenisse ${ }^{216}$ in maiori perfectione, ad praestandum orbi maiorem perfectionem, si ipse sit Deus et homo quam si uenturus esset non Deus sed homo tantum. Nisi uero hoc ita esset, sequeretur quod ex actibus diuinarum dignitatum sequi nequiret tanta perfectio quam ${ }^{217}$ ex actibus uirtutum humanarum. Sed hoc est inconueniens atque falsum; ergo apparet manifeste quod perfectio, quae in hoc mundo finali causae conuenit, ${ }^{218}$ aduenit consistens in aduentu Dei et hominis. Quae quidem perfectio sufficiens est ut homines ab hac uita corporali perueniant ad gloriam sine fine.

Omnis maior perfectio, quae secundum intentionem iudaeorum in aduentu Messiae $\left[R 144^{\mathrm{vb}}\right]$ possit esse, non est tanta sicut perfectio quam christiani

\footnotetext{
214 est add. est $R$.

215 quidem intentio] add. qua $R$; intentio quidem $e$.

216 Messiam aduenisse add. in marg. $R$.

217 quam addidi ex sensu.

218 conuenit correxi ex econuenit $R$.
} 
habent, causa uolendi mori amore cognoscendi et diligendi Deum. Et quoniam ipsi habent super hoc modum praedicandi infidelibus aduentum Dei et hominis, etiam quia mors huius hominis morientis pro suo populo sic $^{219}$ foret exemplum et occasio essendi plures martyres laudando Deum, idcirco demonstrat euidentissime maiorem perfectionem totius orbis esse secundum credentiam quam habent christiani in aduentu Messiae. Ergo minor est illa quam habent iudaei in aduentu Messiae."

\section{De secunda conditione}

Christianus recoluit quomodo antique ${ }^{220}$ iudaei patres propter excessus suos exstiterunt in duabus captiuitatibus, in una per quadringentos annos, in altera uero per septuaginta annos. Sed per ${ }^{221}$ hanc etiam captiuitatem in qua sunt, denotatur ${ }^{222}$ iudaeos nunc ${ }^{223}$ esse culpabiliores erga diuinas dignitates, atque magis egentes uirtutibus quam fuerunt patres eorum in tempore dictarum duarum captiuitatum. Nisi uero hoc ita esset, ergo iustitia in Deo esset contra iustitiam humanam, atque Dei bonitas minor esset in iustitia, et iustitia in homine maior esset in liberalitate. ${ }^{24}$ Hoc autem est inconueniens, quo significatur iudaeos esse $\left[R 145^{\text {ra }}\right]$ in captiuitate, eo quia per negationem aduentui Messiae contrariantur, cui nequaquam essent contrarii, si uenturus esset.

Recoluit christianus perfectionem in diuina sapientia recoluitque perfectionem et sapientiam in uoluntate diuina, et in diuina perfectione sapientiam et uoluntatem, ideoque intellexit quod libertas conuenit libero arbitrio contra captiuitatem qua iudaei detenti sunt, quae siquidem est contraria uirtutibus creatis, eo quia culpa est in eis uirtutibus contraria in quanto est uitiis concordans. Qui quidem uitia habent conuenientiam cum captiuitate habente concordantiam cum poena.

Cumque christianus haec praedicta recoluisset subintulit protinus hoc sermones dicens:

"Si Messias uenturus esset, in tardatione aduentus sui libertas et uirtutes iniuriam paterentur propter captiuitatem iudaeorum, qui praesentes sunt et praeteriti etiam et futuri, priusquam esset illius aduentus. Atque humanae uirtutes inde contrariantur iustitiae diuinae in sapientia diuina, eo quia iudaeis,

\footnotetext{
219 sic correxi ex si $R$.

220 antique correxi ex antiquo $R$.

221 per] post $e$.

222 denotatur] denuo tunc $e$.

223 nunc corr. ex non in marg. $R$.

224 liberalitate corr. ex caritate in marg. $R$.
} 
qui captiuitatem passi sunt, nulla impenditur utilitas secundum iustitiam, nec diuina sapientia ordinauit concordantiam libertatis fidei, spei et caetera.

Captiuitas in qua iudaei mancipati sunt sub christianis et sub sarracenis, ipsis iudaeis poenam attribuit corporalem, quae quidem est inordinatio spiritualis liberta $\left[R 145^{\mathrm{rb}}\right]$ tis, quae cum uirtutibus concordantiam habet. Et idcirco iudaei, qui labores sustinent corporales et in rebus spiritualibus occupati sunt, nullam promerentur habere mercedem pro laboribus, in sua iustitia, fide, spe, fortitudine a diuina iustitia et uoluntate. Etiam in suis laboribus corporalibus et in occupatione suarum intellectualitatum habebunt iudaei utilitatem, qui liberati fient in aduentu Messiae si tamen adhuc sit uenturus. Et sic erit diuina bonitas in iustitia contraria iudaeis qui fierunt in captiuitate, in passione et in regularitate, pro quibus iudaei existentes tunc liberi mercedem retinebunt, quod si sic fuerit, ergo iustitia erit concordans in Deo et in homine cum iniuria et defectu. Hoc autem est inconueniens manifeste, quo euidenter apparet quod aduentus Messiae intelligitur in deliberatione originalis peccati.

Si autem Messias Deus sit et homo, inde maiorem habet concordantiam eius aduentus cum maioritate uirtutis quam si in suo aduentu esset homo tantum, nam aduentus maior est Deo ueniente in hominem et homine in Deum, Christo sic existente Deo et homine, quam sit ueniente homine tantum propter deliberationem hominum a captiuitate. Et in quanto aduentus maior est in tanto maior est utilitas quae sequitur propter aduentum, et etiam desiderium prophetarum oportet esse potius in maiori et $\left[R 145^{\mathrm{va}}\right]$ utiliori aduentu quam in minori atque conuenientia diuinarum dignitatum et humanarum uirtutum, ideo $^{225}$ in eo conuenit esse maiorem. Vnde cum haec ita sint, ergo secundum maiorem concordantiam quae sequitur ex diuinis dignitatibus, humanis dignitatibus et uirtutibus humanis ostenditur manifeste Messiam aduenisse.

Potestas uincendi armis et proeliis maiorem habet concordantiam in rege Deo existente quam in rege homine existente, atque maior est nobilis uincendi potestas per praedicationes, paupertates, humilitates, cruciamina et mortes quam sit terrena potestas per prosperitates uincendi corporales hominum potestates, et uirtus plerumque maior est in spiritualibus quam in corporalibus. Etiam sapientia maiorem habet actum in Deo et homine existente Deo quam in homine qui Deus non existat, atque largitas maior est in Deo existente homine et in homine existente Deo, qui homo mortem passus amore hominem, quam in rege qui tantum sit homo nec mori uellet pro homine nec etiam mori uellet honorando Deum, qui etiam plura bona terrena ${ }^{226}$ quam spiritualia largiatur.

225 ideo in marg. $R$.

226 terrena] terrenam $R$. 
Atque mirabilia maiora sunt in esse hominem Deum et in actibus absque subiecto in Christi corpore consecrato quam sint mirabilia sensibilia de $\operatorname{cor}[R$ $\left.145^{\mathrm{vb}}\right]$ pore Christi, ${ }^{227}$ quae quidem mirabilia de corpore Christi frequentius fuerint quam caetera possint ${ }^{228}$ esse.

Nec non pax maior esse potest inter Deum et hominem quam inter hominem et hominem, et pax maior est inter maius et maius et inter maius et minus quam inter minus et minus; atque pax maior esse potest inter uirtutem et uirtutem quam inter hominem et hominem.

Cum autem haec ita sint, et aduentus Dei in hominem et hominis in Deum omnia significet praedicta secundum maiorem uirtutum concordantiam cum dignitatibus diuinis, ergo manifeste apparet Messiam aduenisse, cuius aduentum ignorant iudaei, eo quod ${ }^{229}$ expectant aduentum Messiae uehementius respectu huius mundi et rerum corporalium quam respectu caelestis saeculi et spiritualium rerum.

\section{$[\text { De tertia conditione }]^{230}$}

Si Messias non adhuc uenerit sed potius uenturus sit, et propter aduentum eius in breui tempore destructi sint actus uitiorum sicut in breui tempore destructi erunt $^{231}$ actus uirtutum, maxime cum actus uirtutum maiores esse possint in quanto plus actus ${ }^{232}$ uitiorum uirtutibus aduersantur in maioritate temporis et in hominibus diuersis. Quoniam nisi sic esset, sequeretur quod nec liberum arbitrium nec actus uirtutum conuenire possent in maioritate uitiis aduersantes conuenirentque liberum arbitrium et uitia, quod tamen est inconueniens; quia si esset conueniens, ergo liberum arbitrium $\left[R 146^{\text {ra }}\right]$ eiusque contrarium idem essent, quod est impossibile manifeste. Quo quidem impossibili designatur euidenter quod propter aduentum Messiae non oportet destrui longitudo temporis, in actibus liberi arbitrii, uirtutum et uitiorum, ut plures homines habere possint magnos actus uirtutum in cognoscendo, diligendo et laudando Deum, et seruiendo ei. Qui, Deus benedictus, causam habet impendendi gloriam magnam pluribus hominibus iustis et scientis, si fides quae credidit et spes quae sperat in ueritate maiorem haberent potestatem seruiendo Deo, si uniuersa gens in una lege tantum consisteret, una fide Deum continens.

\footnotetext{
227 Christi add. frequentius fuerit quam caetera possint esse sensibus corporalibus $R$.

228 possint correxi ex possit $R$.

229 quod] quia $e$.

230 tit. om. $R$.

231 uitiorum, sicut in breui tempore destructi erunt in marg. $R$.

232 uirtutum maiores esse possint in quanto plus actus in marg. $R$.
} 
Prudentia igitur et fortitudo existentes in caritate aduersari possent iustitiae fidei et spei in martyribus et confessoribus mori desiderantibus ut praedicatione ignorantes infideles compellent in Deum credere et amare. Si non spes quae sperat et caritas quae diligit uniuersam gentem in una lege, in una fide existere, essent secundum iustitiam, esset quidem iustitia contra ueritatem in unitate gentium existente in fide, spe, caritate et ueritate.

Et quaelibet harum rerum inconueniens est, quo manifestum est euidenter quod uniuersaliter in quocumque homine, quolibet per se particulariter, licitum est desiderare et laborare ad ducendum omnes homines ignorantes in uiam caritatis, ut in una uera fide, $\left[R 146^{\mathrm{rb}}\right]$ in una credulitate consistant sic, ut iustitia Deum cognosci faciat et amari. Etiam oportet gentes esse particulariter ut ipsi sint materia maioritati actuum conuenientium uirtutibus in laudando Deum et seruiendo illi. Si igitur aduentus Messiae contrarius existeret ordinationem praecedentem, ergo esset contrarius maioritati actuum uirtutum, sed hoc esse inconueniens incidit manifeste.

$\mathrm{Si}$ autem Messias Deus sit et homo, actus quidem uirtutum melius conuenire possunt in eius aduentu quam si ipse Messias solummodo sit homo. Nisi uero hoc ita esset, sequeretur quod iustitia existeret contra maioritatem actuum in fide, spe et caritate, quod est inconueniens manifeste. Quo quidem repraesentatur sanctos prophetas desiderauisse uehementius actus uirtutum per opus Dei uiuentis in homine quam per actus uirtutum ut homo efficeretur nuntius ad deliberandum alios homines, qui homo a prophetis qui antiquitus fuerunt nullam utilitatem faceret nec deliberationem.

Certum et euidenter est non omnes creaturas existere in aequali gradu ad suscipiendum gratiam diuinam, nam diuina gratia maior est in homine quam in plantis, etiam quam in animalibus, atque maior est in uno homine quam in altero, et ideo una uirtus potest inde maiorem gratiam suscipere quam altera, $\left[R 146^{\text {va }}\right]$ prout actus unus uirtutis maiorem habet conuenientiam cum actu alterius uirtutis in uno homine quam in altero. Vnde cum haec ita sint, ergo decet ut uirtus ex Deo possint suscipere, et suscipiant tantam uirtutem et gratiam quod humana caritas, iustitia et sapientia in uno homine sint in ita alto gradu quod ipsae ascendere nequeant plus nec in altiorem gradum. ${ }^{233}$ Et nisi hoc ita esset, sequeretur quod uirtus existens in caritate et hominis sapientia et iustitia essent propter perpetim in potentia et in actu, in quo quidem actu non esset perfectio, cui perfectioni ueniret et ipse actus si potentia incideret in priuatione. Sed quoniam oportet Deum cumplere perfectionem actuum iustitiae, caritatis et sapientiae in homine, ergo oportet Deum esse hominem, in

233 add. supra in marg. $R$. 
quo quidem Deo deueniat in priuationi potentia actuum uirtutum in altiori gradu qui in homine possit esse."

\section{[2.2] [Incipit secunda distinctio] $]^{234}$}

Recoluit christianus quomodo per probationem sanctae Trinitatis et Incarnationis Dei et per perfectionem existentem in mundi ordinatione homo possit Deum cognoscere et amare; atque propter solutionem argumentorum, quae per negationem fecerat iudaeus contra praedicta, probabat manifeste christianus Messiam aduenisse.

Postquam christianus hoc recoluisset iterum recoluit negationem quae ab eo fieri oportebat in secunda distinctione dicens hos sermones, quae sequuntur.

\section{$[\text { Prima conditio }]^{235}$}

$\left[R 146^{\mathrm{vb}}\right]$ Christianus diuisit hanc negationis distinctionem in tres partes ratione conditionum ex quibus conditionatur eius liber, et ideo ad primam conditionem incipiens protulit ista uerba dicens:

"Messias uenturus non est, quia si uenturus esset non uenisset, quia si uenisset et iterum uenturus esset, sic esset defectus in actu diuinae perfectionis per bonitatem, magnitudinem et iustitiam, eo quod primus eius aduentus perfectionem non haberet in Dei sapientia et uoluntate. Si autem eius primus aduentus perfectionem haberet in Dei uoluntate, sic eius secundus aduentus propter superfluitatem haberet imperfectionem in diuina iustitia, sed hoc est inconueniens manifeste."

Christianus recoluit demonstrationem fieri non posse ex aduentu Messiae pro aliqua re existente ultra uoluntatem diuinam, et intellexit demonstrationem fieri posse ex aduentu Messiae in diuina uoluntate per actum bonitatis, magnitudinis, aequalem actui ipsius diuinae uoluntatis, ideoque dixit christianus hos sermones:

"Supposito quod articuli et sacramenta ${ }^{236}$ catholica existant in ueritate, supponendum est per consequens Messiam iam ${ }^{237}$ uenisse, quoniam nisi uenerit, sequitur quod actus diuinae uoluntatis existeret contrarius actui magnitudinis in Dei bonitate, iustitia, $\left[R 147^{\mathrm{ra}}\right]$ sapientia, misericodia, largitate et ueritate, nam eius aduentus non esset diuersus in praedictorum articulorum et sacramentorum forma in hoc quod uenturus esset secundum illum modum quo tradimus eum iam uenisse. Et sic sequeretur differentia esse in persona

\footnotetext{
234 tit. om. $R$.

235 tit. om. $R$.

236 catholica correxi ex catholice $R$.

237 iam add. in marg. $R$.
} 
humanae naturae et in tempore, in qua quidem persona ${ }^{238}$ et in quo tempore illum credimus aduenisse; et omnes christiani qui nunc sunt et qui fuere et qui erunt prius quam Messiam ueniat subiacerent errori et damnationi, et sic forma aduentus eius obiecta foret articulis praedictis et sacramentis in ueritate. Si haec enim essent, etiam quod Messias non uenerit sed post sit uenturus, ergo actus diuinae uoluntatis contrarius est maioritati bonitatis, magnitudinis et caetera. Hoc autem est inconueniens quo demonstratur euidentissime Messiam uenisse, quoniam nisi uenisset sequerentur omnia inconuenientia supradicta.

Si Messias non uenerit sed potius sit uenturus, ergo superfluitas est totum id quod sequitur in Ecclesia Romana, necnon ${ }^{239}$ apostoli, martyres, confessores, uirgines, ordines, miracula caeteraque quae ordinationem Romanae Ecclesiae sequuntur essent omnia superflua, et in tempore in quo sumus contraria ueritati, cum qua siquidem ueritate conueniet ${ }^{240}$ id quod nunc credimus tunc quando uenerit Messias, cuius aduentu conuenient talis ecclesia et tales or $[R-$ $147^{\mathrm{rb}}$ ]dinationes sicut sunt istae, quas nunc habemus. Et nisi hoc ita fuerit, sequeretur concordantia superfluitatis cum ueritate in ueritatis bonitate, in qua habebit ueritas contrarietatem cum bonitate et perfectione, eo quod plura mala maxima sequerentur ex praedicta superfluitate, contraria Dei perfectae iustitiae existente infinite in bonitate, qua infinitate est impossibile malum esse in Dei bonitate.

Si autem haec ecclesia sit ad enuntiandum aduentum Messiae et credat eum aduenisse nec aduenerit, sicut sequitur concordantiam esse inter ueritatem et falsitatem, in quarum quidem concordantia sunt contrariae diuinae dignitates in actualitatibus suis. Qua quidem contrarietate haberent concordantiam cum finitate, defectu, fine et terminatione. ${ }^{241}$

Haec autem sunt inconuenientia, quibus manifeste declaratur Messiam iam uenisse, cuius aduentu non sequuntur aliqua inconuenientia, nec ueritatis et falsitatis concordantia, quae sequerentur si uenturus adhuc esset."

\section{De secunda conditione ${ }^{242}$}

"Aeternitas magis sursum est in perfectione quam durabilitas quae principium habens existat sine fine. Etiam durabilitas existens sine fine maiorem habet similitudinem et proportionem cum aeternitate quam durabilitas finem habens.

\footnotetext{
238 persona in marg. $R$.

239 non add. in marg. $R$.

240 conueniet correxi ex conuenient $R$.

241 defectu, fine et terminatione correxi ex defectus finis et terminatio $R$.

242 tit. in marg.
} 
Et quia hoc ita est, ergo si Messias aduenit, actus fidei, spei et caetera, habent inde maiorem concordantiam cum boni $\left[R 147^{\text {va }}\right]$ tate magna in durabilitate et cum aeternitate et perfectione. Si uero Messias uenturus sit, habent inde fides, spes et caetera minores actus in ${ }^{243}$ concordantia magnitudinis, bonitatis, perfectionis et caetera. Sed cum maior concordantia et maioritas actuum in tempore sint affirmabiles, ergo negandum est Messiam uenturum esse.

Si igitur Messias non uenerit, fides, spes et caritas in tempore in quo sumus habent in potentia suos actus utendo et fruendo aduentu eius habentque in habitu hunc aduentum.

Atque actus iustitiae, prudentiae, fortitudinis et temperantiae per moralia sunt magis sursum in uirtute quam actus fidei, spei et caritatis per spiritualia. Etiam iustitia, prudentia, fortitudo et temperantia maiorem habent concordantiam cum diuina magnitudine quam fides, spes et caritas; et ipsae fides, spes et caritas maiorem habent concordantiam cum minoritate in Dei bonitate, iustitia et perfectione quam iustitia, prudentia, temperantia ${ }^{244}$ et fortitudo. Et haec omnia inconuenientia sunt manifeste, quibus sequeretur quod diuinae dignitates et humanae uirtutes maiorem haberent concordantiam, propinquitatem et similitudinem cum uirtutibus moralibus, et res terrenae cum uirtutibus $^{245}$ theoricis et operibus spiritualibus. Hoc autem est impossibile, ergo, hoc impossibile, negandum est Messiam uenturum esse.

Si enim uerum sit Messiam aduenisse, possibile est erro $\left[R 147^{\mathrm{vb}}\right] \mathrm{rem}$ in uno homine habere maiorem potestatem cum ueritate quam ueritas habeat contra errorem in omnibus hominibus credentibus Messiam aduenisse, qui siquidem homines habent ita pro obiecto in ueritate aduentum Messiae sicut habebunt homines qui erunt in illo tempore quando Messias ueniet credentes in aduentu illius. Differentia uero erroris et ueritatis est tantummodo per tempus et diuersitatem hominis, qui iam uenit qui Messias Deus est, et hominis illius, qui uenturus est quem etiam appellabunt Messiam.

Sed cum diuina ueritas concordantiam habeat cum maioriate in infinita bonitate, magnitudine et iustitia, et error ${ }^{246}$ concordantiam habeat cum priuatione et minoritate, et habeat etiam concordantiam maiorem cum maiori malo quam cum minori, ergo apparet manifeste in magnitudine ueritatis per iustitiam et per perfectionem quod error nequit in uno homine capere tantum principium quod insequatur tam magnum antecedens et consequens, ut superet ueritatem diuinam in diuina magnitudine, bonitate, iustitia et perfectione;

\footnotetext{
243 in add. in marg. $R$.

244 temperantia add. in marg. $R$.

245 moralibus et ... uirtutibus add. in marg. $R$.

246 error correxi ex errore $R$.
} 
quia si sic, sequeretur igitur quod iustitia ${ }^{247}$ humana iustificare posset spem desperantem et caritatem odientem actum diuinarum dignitatum, quae siquidem iustificatio inconueniens est, quo quidem inconueniente negando est metaphorice Messi $\left[R 148^{\text {ra }}\right]$ am ullo tempore aduenturum."

\section{[De tertia conditione]}

"Certum et uerum est quod viI uitia mortalia, uidelicet gula, luxuria, auaritia, superbia, accidia, inuidia et ira sunt cum concordantia in suis actualitatibus contra uirtutes, si Messias uenerit; etiam actus eorum concordantiam habent cum priuatione et defectus. Si autem Messias non uenerit, sequitur quod uirtutes existentes in christianis qui nunc sunt non habeant in quo conuenire quaerant in rebus maioribus contra uitia, atque uitia habere possunt concordantiam in rebus maioribus contra uirtutes. Sed quoniam uirtutes concordantiam habent cum esse et perfectione quae cum maioritate conueniunt, ergo in maioritate uirtutum et uitiorum aperte manifestum est Messiam iam uenisse. Si non, eius aduentu uirtutes in christianis conuenirent per habitum et obiectum cum maioritate uitium, ${ }^{248}$ etiam ipsi christiani conuenirent per actum, habitum et obiectum cum maioritate uitiorum. Qua quidem conuenientia eorum uirtutes haberent concordantiam cum actuum minoritate. Hoc autem est inconueniens et contra iustitiam, prudentiam, fortitudinem, temperantiam in fide, spe et caritate.

Si uero Messias non uenerit sed potius sit uenturus, sequitur inde contrarietas inter uirtutem et uirtutem et concordantia inter uitium et uirtutem, quoniam si uenturus sit et ueniat secundum formam et statum quibus fides credit eum uenisse, quando ipse Messias uenerit fides discredet et dubitabit eum uenisse, et spes sperabit eum uenturum esse, ne caritas diliget illum Messiam, sed post dubita $\left[R 148^{\mathrm{rb}}\right]$ bit aduentum alterius Messiae, et sic ipsae tres uirtutes contrariabuntur iustitiae, prudentiae et fortitudini, quia propter fragilitatem ipsius fidei, spei et caritatis generabitur dubitatio utrum Messias uenerit aut non, nam memoria recolet quod sicut modo sumus in errore si Messias non uenerit ita tunc, quando ueniet, haesitabunt homines eum non uenisse.

Si tamen hoc sit, quod una uirtus sit alteri uirtuti contraria, ergo oportebit unum uitium esse contrarium alteri uitio, et quod uirtutes et uitia sint pariter concordantes. Sed hoc est inconueniens et impossibile, ergo manifeste declaratur Messiam iam uenisse. Si autem Messias uenturus sit et ueniat secundum modum per quem fides credit eum iam uenisse, de necessitate oportet sequi concordantiam esse uirtutis et falsitatis in principio fidei et credulitatis,

247 iustitia $a d d$. et perfectione quia si sic sequeretur igitur quod iustitia $R$.

248 uitium correxi ex uirtutum $R$. 
quoniam fides credens in ueritate, credendo Messiam uenturum esse in qualitate et $^{249}$ in statu in quibus debet ipsa discredere eum uenisse si non uenerit, est in eodem actu et in eodem tempore in ueritate et falsitate. Et in principio quod fides credit et discredit, et in medio per quod medium est principium ut sit finis, existit fides in illo errore et in eadem ueritate. Et hoc idem $\left[R 148^{\mathrm{va}}\right]$ faciunt fides et eius contrarium in causa finali ad quam mouetur medium; et similiter consequitur hoc idem de caeteris uirtutibus si Messias sit uenturus, et hae quidem consequentiae sunt contra uirtutes et uitia in uno obiecto, in uno actu, in uno tempore et in eodem subiecto. Sed quoniam talis inconueniens impossibile est, ergo manifestum est Messiam uenisse."

\section{[EPILOGVS]}

Christianus itaque expediens ${ }^{250}$ suum librum terminauit exhortans iudaeum dulcissimis sermonibus ut conuersus sanctam fidem catholicam acceptaret, et, si dubitaret eam suscipere, supponat ipsam fidem catholicam esse ueram aut falsam, quia naturae est intellectus se exaltare ad inquirendum uerum et falsum per suppositionem ueri et falsi. Cum autem intellectus per fidem non supponit uerum aut falsum, non habet cum quo generare possit suum intelligere in habitum per quem transit de potentia in actu, sed phantasticus permanet et occupatus propter rememorationem et uoluntatem, quae nimis aliquo utuntur obiecto nimis memorando et nimis diligendo id, in quo quidem intellectus nequit discernere uerum a falso, nec cognoscere in tribus conditionibus quibus hic liber discurrit utrum christianus autem iudaeus maiorem habeat concordantiam, secundum ${ }^{251}$ cuiuslibet articulos cum conditionibus in maioritate esse et perfectione contra minoritatem, priuationem et defectum.

Auditis ${ }^{252}$ hiis rationibus ab utroque $\left[R 148^{\mathrm{vb}}\right]$ sapientium et pulcro ordine terminatis, ambo $^{253}$ longanimiter cogitarunt inter se ad inuicem alter alterum speculantes, altero alterum suadente, ut in lege sua conuerti deuotae dignaretur. Verumtamen super haec conuenire nequiuerunt, eo quia haec disputatio fuerat ${ }^{254}$ in eorum considerationibus nouiter agitata. Quocirca proposuerunt se perseuerare diu in disputationibus secundum modum et ordinem supradictum, ut eorum intellectus in hiis praemissis rationibus fierent assidui

\footnotetext{
249 et add. iustitia sed corr. $R$.

250 expediens corr. ex expendisse in marg. $R$.

251 secundum add. cum sed corr. $R$.

252 Auditis $a d d$. priuationum et defectuum $e$.

253 amboom.l.

254 fuerat] fuerit $e$.
} 
iudicantes, quis amborum melius conueniret cum tribus praehibitis conditionibus in affirmatione et negatione aduentus Messiae.

Sic ambo sapientes conuenientes statuerunt inter se in synagogis et in ecclesiis disputare in sapientium iudaeorum et christianorum praesentia, ut per aduentum Messiae significatum melius per tres conditiones fortificarentur melius $^{255}$ illi qui existunt in semita ueritatis. Quisque duorum sapientium modum habebat quomodo intrare poterat in quaestionem in conuentu caeterum sapientium, nam christianus et iudaeus ab aliis sapientibus inquirebant quis eorum melius concordans existebat ${ }^{256}$ cum rationibus et actibus intellectus et uoluntatis in cognoscendo et diligendo Deum seruiendoque ei secundum tres conditiones in praehibitis declaratas; ${ }^{257}$ ea propter multae fiebant quaestiones et solutiones hinc et inde, et in quanto fortius disputabant inquirentes expresse ueritatem percipere $\left[R 149^{\text {ra }}\right]$, in tanto fortius apparebat in aduentu Messiae ueritas manifesta.

Diu perseuerauit christianus in disputationibus cum hoc iudaeo et cum aliis sapientibus iudaeorum manifestans rationes suas, et rationes iudaei pluribus christianis. Iudaeus etiam hortatus fuit plerumque christianum ut iterum in silua in qua prius fuerant morarentur disputantes secundum primas ${ }^{258}$ rationes super hiis quae ${ }^{259}$ audiuerant ex sermonibus sapientium, cui christianus placide respondens dixit se satis sufficienter cum eo disputasse, et excusans se, eo quod tractaturus erat de quodam libro quem compilauit contra Antichristum et aduentum eius, ad laudem et seruitium illius, qui est benedictus per omnia saecula uerus Deus. ${ }^{260}$

Explicit Liber de aduentu Messiae.

255 per tres ... melius add. in marg. $R$.

256 quis eorum ... existebat iter. $R$.

257 declaratas] correx. ex declaratis $R$; declaratis $e$.

258 ueras $e$.

259 haec quae] huiusque $e$.

260 uerus Deus] saeculorum $l$. 

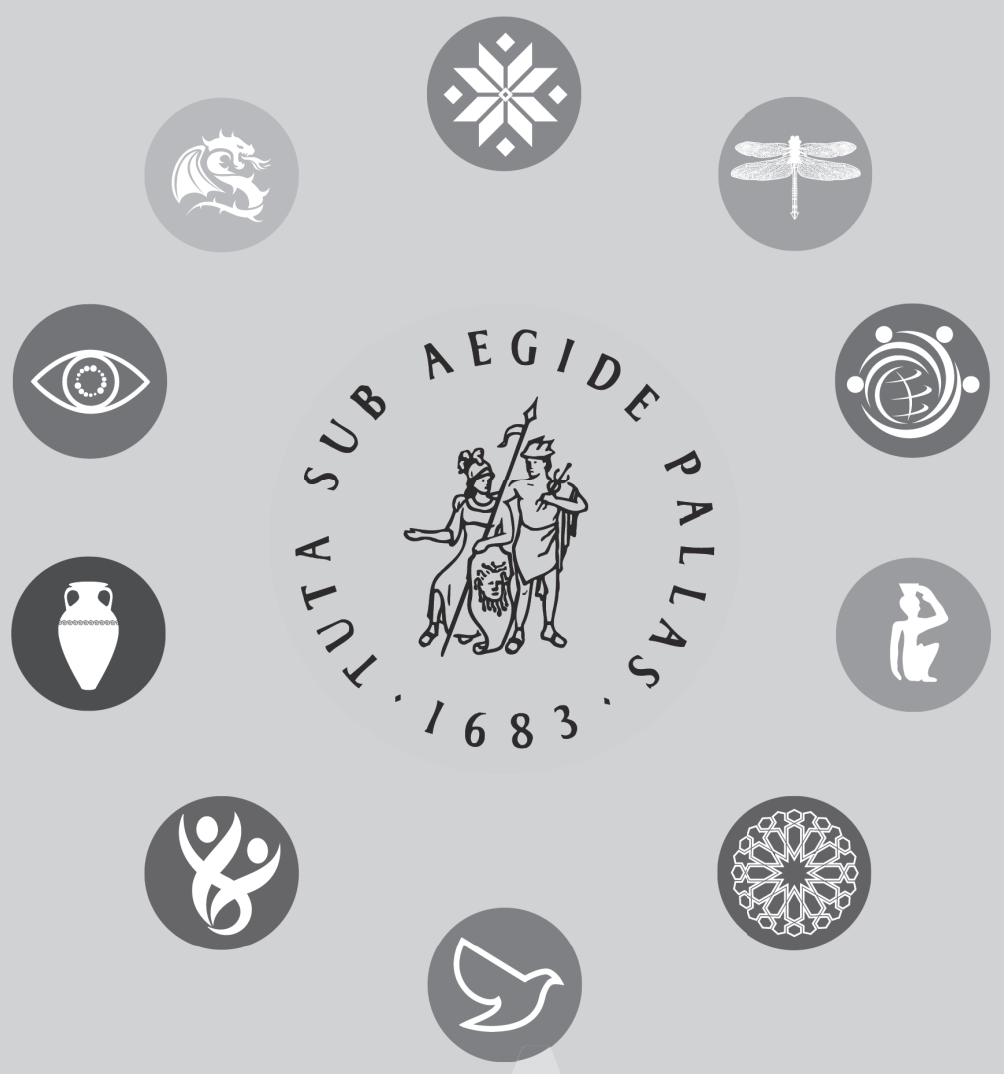

\section{Discover Together}

\section{Take a tour of the new brill.com}

- Simplicity: clean and easy to use interface

- Ease of Use: content discoverable on one platform

- Integrated Search: integrated search refinement, easy use on mobile

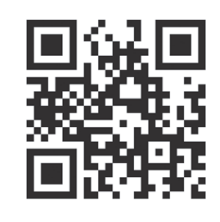




\section{Take your manuscript to the next level}

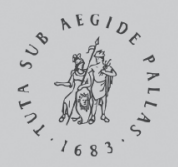

B R I L L

\section{authorservices.brill.com}

Make the process of preparing and submitting a manuscript easier with Brill's suite of author services, provided by Peerwith.

Find the right expert in language editing, copy editing, visuals production and many other areas, to take your academic work to the next level.

\section{How it works}

Author Services is an online marketplace, matching academics seeking support for their work with experts who can help out with language, visuals, consulting, or anything else that scholars need.

\section{How to get started}

\begin{tabular}{|c|c|c|c|c|}
\hline $\begin{array}{l}\text { Write } \\
\text { your } \\
\text { request }\end{array}$ & $\begin{array}{c}\text { Get a quote } \\
\text { and choose } \\
\text { expert }\end{array}$ & $\begin{array}{l}\text { Agree on } \\
\text { the fee and } \\
\text { conditions }\end{array}$ & $\begin{array}{l}\text { Pay using the } \\
\text { secure PayPal } \\
\text { system }\end{array}$ & $\begin{array}{c}\text { The work } \\
\text { can } \\
\text { begin! }\end{array}$ \\
\hline
\end{tabular}

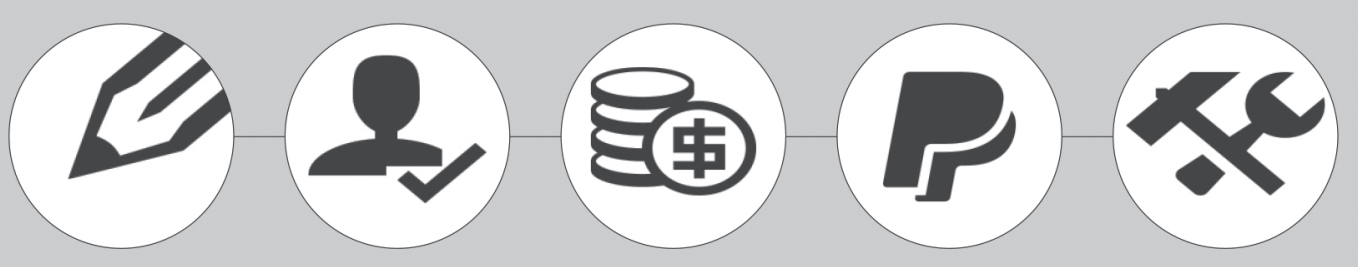

